\title{
The Discursive Constitution of Ocean Sustainability
}

\author{
Ulrike Kronfeld-Goharani \\ Institute of Social Sciences, Kiel University, Kiel, Germany \\ Email: kronfeld@ips.uni-kiel.de
}

Received 25 November 2015; accepted 22 December 2015; published 25 December 2015

Copyright @ 2015 by author and Scientific Research Publishing Inc.

This work is licensed under the Creative Commons Attribution International License (CC BY). http://creativecommons.org/licenses/by/4.0/

c. (i) Open Access

\section{Abstract}

As part of a search for political responses to protect and conserve marine ecosystems, this study explores the discourse on ocean affairs with a special emphasis on the articulation of the concept of sustainability. Drawing on the discourse theory of Ernesto Laclau and Chantal Mouffe, it is argued that post structuralism offers important insights on the construction of the discourse on maritime-related affairs. The analysis shows that the discourse on ocean affairs is closely tied to the empty signifier "management", while the analysis of the empty signifier "sustainability" confirms the traditional three dimensional structure comprising economic, social and environmental dimensions, supplemented by an institutional one. The article shows that the use of such signifiers is necessary to define sustainability in all its complexity. In this context, it is argued that Laclau and Mouffe's discourse theory provides an approach to grasp the ambiguity of the concept of sustainability. It helps to explain the practice of institutions in rephrasing existing objectives and activities in compliance with sustainability without really changing their business as usual approach. The paper concludes with an estimation of how useful it is to adhere to sustainability in ocean affairs especially in view of the complexity, uncertainty and continuous change of marine ecosystems.

\section{Keywords}

Ocean, Sustainability, Discourse Theory, Crisis, Hegemony

\section{Introduction}

In comparison with climate change policies, the threat to ocean health has not been acknowledged as widely despite its far-reaching consequences for international politics. While human-induced climate change has become an urgent issue on political agendas and is increasingly articulated as a major security concern in media and public discourse, the impact of climate change on the ocean has been largely ignored in political discussions 
(United Nations General Assembly, 2009: p. 12). For instance, most international efforts to limit greenhouse gas (GHG) emissions disregard the "other $\mathrm{CO}_{2}$ problem" despite growing evidence that the increasing acidification of the world's oceans might be the greatest threat facing marine species and ecosystems with unpredictable economic consequences (Doney, 2009; Feely et al., 2006; Mora et al., 2013; Royal Society, 2005; Service, 2012; Turley, 2005). Compared with public concern over climate-related changes in the world, the meaning of the ocean as a buffer for atmospheric $\mathrm{CO}_{2}$ and the impact associated with the increase in GHG have not been adequately conveyed within international politics and to the general public (SCOR/IOC Symposium Planning Committee, 2004: p. 8). This is quite remarkable given that the ocean as the Earth's life-supporting system plays a key role for human wealth and well-being. Humankind obtains a multitude of benefits from marine ecosystem services that provide us with food, fresh water, oxygen, raw materials and marine active substances, regulate climate, emission absorption and shoreline protection, support livelihoods as well as job creation and offer opportunities for recreational, spiritual and aesthetic pleasures. These benefits are highly at risk after using the marine ecosystem as a disposable commodity for centuries without caring what was happening to ocean health. The principle of the "mare liberum" formulated by the Dutch jurist Hugo Grotius (1609) that allowed each person free access to the sea and use of its resources can be articulated as to have exercised a negative impact on marine ecosystems. When in 1994 the United Nations Convention on the Law of the Sea (UNCLOS) treaty entered into force and the concept of Exclusive Economic Zones (EEZs) was accepted, 64 percent (Clark et al. 2006: p. 6; Kimball, 2005: p. iii) of the high seas were still not subjected to national sovereignty and thus continued to represent an open access source to anyone who has the means (Costanza 1999: p. 199). The free access to and the availability of marine resources have wielded strong pressure on maritime spaces that have been exposed to challenges emerging from the dynamics of developments in various branches of the maritime economy, especially in the fisheries industry, sea traffic, offshore wind energy, aquaculture and tourism. The strong use of ocean resources in combination with an ongoing pollution of marine spaces have led to a degradation of 60 per cent of the world's major marine ecosystem (IOC/UNESCO et al. 2011: p. 8) which is increasingly threatened by unsustainable fishing practices, pollution, waste, invasive species and climate change (e.g. Bijma et al., 2013; Doney et al., 2012; Maribus, 2010; Pitcher et al., 2013; Worm et al., 2012). Today, there is no such place where marine nature is undisturbed as hazardous substances or other kind of pollution in the ocean are not restricted locally but can be transported by currents and also do harm in far distant areas from the polluter. The conservation and protection of the ocean, with large areas that are still not very well known, demands a more careful use of marine resources and dealing with waste to ensure our needs as well as those of future generations (World Commission on Environment and Development, 1987: p. 43). In this context, the concept of "sustainability" may provide a conceptual basis for integrating these requirements. However, the concept that has become the worldwide dominating leitmotif for shaping international environmental and developmental relations, suffers from vagueness. The definitional ambiguity and the variety of possibilities for characterizing the term, the confusion of terminology, data, and methods of measurement have led to a situation in which the concept is used in a multitude of contexts (Parris and Kates, 2003: p. 13.23). Thus, there is a strong need to develop a common ground to understand what sustainability actually means. This is especially true for the recently agreed SDG 14 of the United Nations 2030 Agenda for Sustainable Development.

The present study thus investigates the discourse on maritime-related affairs with special emphasis on the articulation of the concept of sustainability. Starting from the current debate on sustainability with special reference to ocean-related affairs (Section 2), in Section 3 the underlying theory for this analysis based on the poststructuralist discourse theory of Ernesto Laclau and Chantal Mouffe is introduced. The subsequent Section 4 outlines the material for the analysis, which covers 2108 whole text files related to ocean affairs during the second phase of the Rio Process (2002-2012). Sections 5 and 6 present a comprehensive analysis of how the discourse on maritime affairs is structured. The study identifies the key signifiers in the organization of the discourse on ocean affairs, asks how they are filled with meaning, which actors and lines of argumentation are decisive and by which groups the discourse is constituted. It will be shown what kind of a picture of sustainability is construed in the hegemonic process and how the ambiguity of meaning of the concept can be explained. The last Section 7 concludes with a discussion of the results and makes a proposal to the conceptualization of sustainability in ocean affairs especially in view of the complexity, uncertainty and continuous change of marine ecosystems.

${ }^{1}$ The ocean acts as a great buffer absorbing a portion of man-made carbon dioxide from the atmosphere thus reducing the most severe consequences of climate change. However, the additional human-made carbon dioxide disturbs the chemical equilibrium of seawater (Maribus, 2010: p. 211). 


\section{Ocean Sustainability: Current State of the Debate}

Marine pollution, which has been a concern since the late 1950s and early 1960s, was one of the topics discussed at the United Nations Conference on the Human Environment (UNCHE) in Stockholm. Topics on the agenda included the dumping of radioactive waste by nuclear power companies and experiences with oil spills. In the years that followed, several marine conventions were adopted, amongst them the Convention on the Prevention of Marine Pollution by Dumping of Wastes and Other Matter (1972) and the International Convention for the Prevention of Marine Pollution from Ships (1973).

Ongoing environmental degradation, the impoverishment of the world's natural resources and their unequal distribution between developed and developing states were central concerns expressed in a series of reports published in the early 1980s (e.g. Brandt, 1980; The Global 2000 Report to the President, 1980; United Nations General Assembly, 1982). This was the broader political context in which the concept of sustainable development began to be understood in a wider sense than forestry. The Brundtland Commission then provided the first definition of sustainable development, based on the realization that the prevailing growth-oriented development model not only endangered the well-being of the present but also that of future generations (World Commission on Environment and Development, 1987: p. 43).

The new definition of the concept demanded multilateralism and an interdependence of nations for its implementation. It attracted international attention and was adopted by the 1992 UN Conference on Environment and Development (UNCED) in Rio de Janeiro. There it was included in several significant documents, inter alia the Rio Declaration on Environment and Development and the Agenda 21, with chapter 17 devoted to ocean affairs. In 2000, ensuring environmental sustainability ${ }^{2}$ was agreed upon as the seventh of eight UN Millennium Development Goals. The concept's perception experienced a major shift at the World Summit on Sustainable Development (WSSD) in Johannesburg (United Nations, 2002) "away from environmental issues toward social and economic development” (Drexhage et al., 2010: p. 8).

Since then several models have emerged that facilitate the comprehension of the concept. The most widely known is the "three-pillar"-model aiming at the development of the environmental (conservation), economic (growth), and social (equity) dimensions of society. The "egg of sustainability"-model assumes that sustainability can only be achieved if there is a balance between human well-being and ecosystem well-being (Guijt and Moiseev, 2001: p. 21) whereas the "prism”-model is based on an economic, environmental, societal and an additional institutional dimension (Spangenberg, 2002: p. 305). Some critics of these rather simple models argue that they contributed to the conceptual vagueness and confusion in terminology of sustainability (e.g. Parris and Kates, 2003).

Regarding the long-term perspective of the concept it is an additional hurdle that human values, norms and needs change with time so that policies have to be adapted from time to time (WBGU, 1998: p. 54). As human well-being depends to a large extent on coastal and ocean resources, questions arise how human welfare can be maintained in the future, how it can be distributed in a fair and equitable way and what level of conservation of natural resources is needed. In this context, another approach to conceptualise sustainability came up: the debate on "strong”, "intermediate" and "weak" sustainability (e.g. Daly and Cobb, 1989; Pearce et al., 1989; Hartwick, 1990; Atkinson, 1997; Neumayer, 1999; Ott, 2014). This concept assumes that human welfare depends on various types of capital: natural capital (raw materials such as fish, minerals, oil and gas as well as ecosystem services providing food, energy, climate regulation and medicine), cultivated natural capital (e.g. aquaculture), social capital (e.g. political institutions), human capital (e.g. skills, education) and knowledge capital (Schultz et al., 2008: p. 468).

The concept of "strong sustainability" does not allow any substitution of human or human-made capital for natural capital, as natural and man-made capital are phrased not to as substitutes but rather as complements ${ }^{3}$ and that maintaining stocks of natural capital requires strong management rules (Visbeck et al., 2014: p. 188). In contrast, "weak sustainability" refers to the-in the western developed world—prevailing approach of substituting natural goods and services to a sufficient degree by human-made goods and services (Baumgärtner et al., 2010: p. 3). Williams and Millington (2004: p. 101) note that the weak sustainability concept is based on faith in scientific and technological expertise and the belief that humankind will be able "to solve any problems that may arise concerning resource depletion" through technological development. Critics however argue that there are

\footnotetext{
${ }^{2}$ The preferred use of either the term "sustainable development” or "sustainability" depends on the context. After e.g. Robinson (2004: p. 372 ) the first term is more used in a technical sense, the second one in terms of a value change. ${ }^{3}$ Ibid.
} 
elements of the biosphere that cannot be traded off, e.g. species, thus limiting substitution (Schultz et al., 2008: p. 468).

Beyond the debate on the maintenance of natural capital the ocean is still a place of discovery of which large parts still remain not well known. Its interaction with other systems of planet Earth such as the atmosphere, hydrosphere, geosphere, and biosphere constitutes a highly complex system. This complexity and the uncertainty about the future behavior of marine ecosystems under growing pressure in the Anthropocene (Crutzen, 2002: p. 23) and the provision of global collective goods that are non-excludable and non-rivals in consumption (Kaul, 2013: p. 10) present extremely demanding challenges of governance (Underdal, 2010: p. 386).

Against this backdrop and in order to investigate the discursive constitution of the ocean and to further clarify how sustainability is used in ocean affairs the next section briefly introduces the underlying theoretical concepts, based on the discourse theory of Ernesto Laclau and Chantal Mouffe, who propose an ontology of the social that highlights the notions of hegemony, antagonism and universalism with regards to how dominant political meanings evolve.

\section{The Discourse Theory of Ernest Laclau and Chantal Mouffe}

In the field of discourse theory, different understandings of the notion of discourse exist. For instance, it is referred to as "a slippery term which draws from plentiful research traditions in social and linguistic theory" (Nabers, 2009: p. 192). Keller, Hirseland, Schneider and Viehöver (2010: p. 10ff.) distinguish four different traditions of how the term is used: 1) in the Theory of Communicative Action by Jürgen Habermas; 2) in "discourse analysis" as a conversation and communication analysis; 3) as a cultural or interpretative turn and 4) as a discourse theoretical approach. This study focuses on the last concept, which is thought to be particularly fruitful to investigate "broad societal and cultural developments such as globalization” (Jørgensen et al., 2002: p. 2).

Drawing on Laclau and Mouffe's discourse theory, this study explores the social constructions inherent in discourses related to maritime affairs. One basic idea underpinning the poststructuralist notion is that arguments do not originate in the thoughts of individual people and that speakers do not create their thoughts in the first instance, but that each are embedded in a complex socio-linguistic history. In this context, the use of language "and its symbolic analogues exercise the most crucial determinations in our social relations, our thought processes, and our understanding of who and what we are” (Belsey, 2002: p. 6). Following Ferdinand de Saussure's approach, language can be understood as a system of signs that enables the constitution of meaning as an effect of the relationship between (linguistic) elements. It is the function of discourse to tie out particular elements, which are connectable to others in a specific situation and thereby transform them into what Laclau and Mouffe call moments in a discourse (Laclau and Mouffe, 2001[1985]: p. 105, 111).

\subsection{Understanding "Discourse”}

Understanding meaning as constituted by differences between objects within discourse, Laclau and Mouffe assume that there is no social field independent of discourse and that the social can only be formed by discourse. There is no given system or pattern to which a discourse is aligned. Discourses are unsteady and continuously changing. Within specific discourses, political identities and societal power relations are constructed that are temporarily fixed with meaning by processes of hegemony and sedimentation and thus are being conceived of as social reality. Discourse theory implies that social relations are always volatile and temporary results of discursive arguments (Glasze and Mattissek, 2009: p. 158). As reality always produces a surplus of meanings or a "field of discursivity" (Laclau and Mouffe, 2001[1985]: p. 111), the discourse is continually exposed to new meanings seeking to establish themselves within the discourse. Laclau and Mouffe assign the status of floating signifiers to the elements. Floating signifiers are not fixed to a certain signified but are of an ambiguous character. They are empty (or emptied) signifiers. Floating signifiers can assume different meanings for different social groups depending on the nature or topic of the discourse; examples are expressions like "freedom" and "equality”. In a similar fashion, signifiers are characterized by an indistinct or non-existent signified, i.e., terms that can have different meanings and can thereby serve to unite disparate social movements (Laclau and Mouffe, 2002 [1985]: p. 113). As the social consists of the construction of new differences, Laclau and Mouffe equate the social with articulation and assume that the fixation of a system of differences by the articulatory practice not only consists of linguistic phenomena but can also penetrate the entire material density of institutions, rituals and practices (Laclau and Mouffe, 2006: p. 145). Each social relation is shaped by different characteristics such as antagonism, hegemony and dislocation. 


\subsection{Antagonism}

The concept of identity understood as a "function of differences within a system" (Culler, 1986: p. 36) is closely linked to an empty signifier. Identity-building processes that are characterized by the reduction of differences to a common denominator, simultaneously constitute an antagonistic outside. This outside epitomizes all features that jeopardize the own identity and thus must be excluded from it (Glasze and Mattissek, 2009: p. 164). As each identity is threatened by an antagonistic outside, the complete constitution of identity or the closedness of the discourse can never be achieved. Thereby, antagonism performs two contradictory tasks: On the one hand, common identity is only constituted by a common antagonism towards a radical outside. On the other hand the outside "both denies that identity and provides its condition of possibility at the same time" (Laclau, 1990: p. 39).

The principle of structural undecidability implies that the relation between two different groups that have taken different decisions are characterized by antagonism and power "since no ultimate rational grounds exist for their opting either way." ${ }^{4}$ Furthermore, Laclau concludes that "all objectivity necessarily presupposes the repression of that which is excluded by its establishment". ${ }^{5}$ Therefore, the concept of power is of central importance in the Laclauian identity theory as identity cannot be thought of as independent from power: "Our thesis is that the constitution of a social identity is an act of power and that identity as such is power" ${ }^{\prime 6}$. Consequently, the investigation of a given social identity always means the study of the power mechanisms that enable them.

\subsection{Hegemony}

Following Laclau and Mouffe, two requirements must be fulfilled for hegemony to occur: first, the elements of a discourse must be floating signifiers in the field of articulatory practices and second, the articulation must be able to take place "through a confrontation with antagonistic articulatory practices" (Laclau and Mouffe, 2001 [1985]: p. 136). Based on Gramsci's concept of a political space, Laclau distinguishes between struggles where a multitude of political spaces are involved (democratic struggles) and those "where certain discourses tendentially construct the division of a single political space in two opposed fields" (popular struggles) ${ }^{7}$. This corresponds to his concepts of democratic and popular subject positions. While in his understanding the notion "democratic subject position" refers "to the locus of a clearly delimited antagonism which does not divide society in that way", the latter is phrased as a position "constituted on the basis of dividing the political space into two antagonistic camps." ${ }^{8}$ Radical struggles in countries of the Third World are an example of popular struggles, while in modern industrialized countries the increasing number of antagonisms enables the growth of democratic struggles ${ }^{9}$.

\subsection{Dislocation}

The universal is conceived as exclusively consisting as a form of an absent fullness. In a hegemonic process different particularisms compete to take the empty place of the universal. In this context and to describe all the events that cannot achieve any integration into existing discourses and that can undermine or break current structures, Laclau and Mouffe (2001 [1985]: p. 142) introduced the concept of dislocation, meaning that "every identity is dislocated insofar as it depends on an outside which both denies that identity and provides its condition of possibility at the same time" (Laclau, 1990: p. 39). The more radical the dislocation the greater the possibilities are for the formation of new discursive linkages ${ }^{10}$. The attempt to overcome dislocations by the new articulation of dislocated elements is called myth by Laclau ${ }^{11}$.

A dislocation can be an external catastrophe like a major war, a grave economic crisis (Nabers, 2007: p. 23) or an undecidable situation that demands that a political decision be taken. In this context, the concept of the empty signifier becomes important as it can assume a new meaning, thus acting as a floating signifier. The rela- 
tion that converts a particular content into a universal (empty) signifier, Laclau calls hegemonic (Laclau, 1996: p. 74). As an example Laclau mentions the term "democracy" that can take on completely different meanings when used in the context of anti-fascism or anti-communism (Laclau, 1990: p. 28). The possibility of an empty signifier becoming universal depends on several conditions: first on the normative framework of a society. This is constituted by sedimented fixations, fixations that have become so consolidated that they are conceived of as social reality. Second, the more a particular political project corresponds with the normative framework the higher its chance of being universally accepted (Laclau, 2000a: p. 82).

\subsection{Equivalence and Difference}

Finally, the concept of an empty signifier is closely connected with two other logical concepts: the logic of equivalence and the logic of difference. The logic of equivalence constitutes the fullness of a community by linking together a plurality of unfulfilled demands, while difference contradicts this logic. Different identities are grouped together in opposition to another camp to form a chain of equivalence, yet identities appear to be fixed by articulating a subject into a sequence of signifiers. The structure of the whole forms a separate discourse that constitutes a specific meaning within a chain of moments (Glasze, 2008: p. 192). Based on these considerations Laclau and Mouffe conceive of the logic of equivalence as a logic of simplification, and the logic of difference as an extension of the complexity of the political space (Laclau and Mouffe, (2001)[1985]: p. 128).

\subsection{From Theory to Practice}

Laclau and Mouffe focused "on the ontological dimension of social theory" (Laclau, 2004: p. 321) without making any reference to an application of their theory. Various proposals have been made to fill this methodical gap. While some scientists, e.g. Jørgensen and Philipps (2002: p. 49), argue that the Laclau and Mouffe's theory can be applied without any other discourse analytical methods, others regard the combination of Laclau's discourse theory with Critical Discourse Analysis (CDA) as fruitful, although with major qualifications (Nabers, 2009: p. 199). This study follows a recommendation of Glasze (2008) to apply a triangulation of a lexicometric approach in combination with an analysis of narrative patterns.

\section{Analyzing Language: A Corpus-Linguistic Approach}

The focus of the present analysis is not on the interpretation of single texts but on the use of language in large text groups. The period under consideration covers the last decade of the Rio process (2002-2012), taking into account that the sustainability concept experienced a major shift in this time as outlined above. For this time period English-language texts of regular maritime-related publications (annual reports, meeting and conference reports, newsletters, official documents, circular letters, statements and speeches) from important UN agencies, the EU, intergovernmental and nongovernmental organisations and scientific publications have been selected and downloaded from the internet. For each text, all bibliographical data on titles, authors etc. are available. For the lexicometric analysis all texts have been converted to plain text formats and paratextual features such as titles, contents, bibliographies, footnotes and figures have been removed. To generate the corpus there has been an attempt to collect regular publications as completely as possible. However, in some few cases downloads were not possible due to corrupted files and some of the data files were scanned versions and thus inadequate for the computer-based analysis. Furthermore, there is a slight selection bias in the corpus on behalf of developed countries because there is more infrastructure in place and more publications are available. The present corpus comprises a collection of 2,108 whole texts that represent a sample and cross-section of ocean-related discourse (Figure 1). In the period under consideration, the number of available sources on the internet has constantly increased with the exception of 2011.

The lexicometric analysis has been conducted using the software Word Smith 6.0 (Scott 2012). Word Smith offers three functions that guide the first step in the analysis: WordList generates a list of all the words or word-clusters in a text, Concord allows to examine any given word or phrase in context, making it possible to observe so called co-occurences in a text, i.e. concepts that occur more often in the environment of an empty signifier. The tool KeyWords makes it possible to identify the key words in a text, those words whose frequency is unusually high in comparison with some norm thereby enabling the researcher to investigate language patterns in large text corpora (Nabers, 2009: p. 199). 


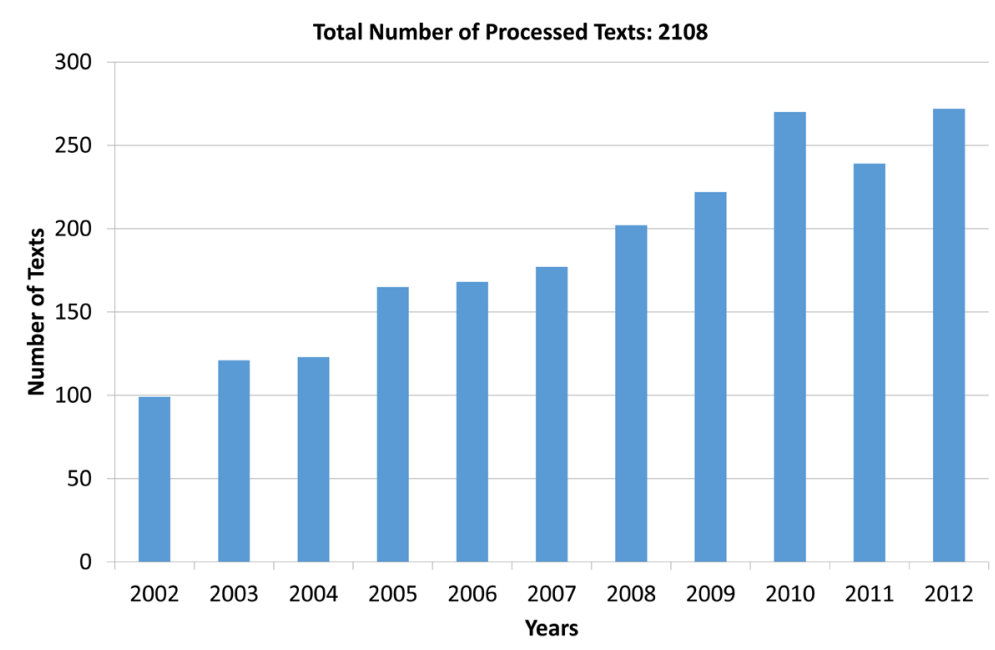

Figure 1. Total number of processed texts: 2108. Source: Own Calculation.

Linguistic methods enable the examination of differences between lexical elements and the analysis of their temporal fixation in a diachronic comparison and can provide information on characteristics of subcorpora as well as of continuities or dislocations of the discourse. But they cannot give any evidence of the quality of linguistic combinations i.e. referring to temporality or causality. Therefore, several texts of international conventions, statutes of various stakeholders, etc. have been integrated into the investigation of the narrative patterns to complement the contextualization of findings of the lexicometric analysis.

\section{The Discourse on Ocean Affairs}

The aim of an initial analysis was to count frequencies to uncover the relevant elements of the discourse related to ocean affairs. The word list generated using Wordsmith (Table 1) gives an overview of the type of vocabulary used and the discursive nodal points.

The table shows the absolute frequencies (column 3), the relative frequencies (column 4) and the frequencies of a word in all texts (column 6). The most often named frequencies over a decade are "management", "sea", "fisheries", "data" and "fishing", indicating that the discourse is mainly about management and marine fisheries. The term "species" can relate to fisheries, protection measures for special species and the harmful impact of e.g. invasive species but also to the protection of and the need for scientific "information" supported by "data" about the state of marine fish stocks, species and sizes, fish habitat modifications, pollution and other factors affecting the fisheries sector. The term "areas" also has an ambiguous meaning and can apply to high seas areas and those under national jurisdiction as well as fishing, aquaculture, wetland, coastal and conservation areas. The notion "development" can relate to sustainable, economic, social, international, fisheries, policy or tourism development. "Information" provides a first hint that information and science providing data on marine affairs could play an important role in the discursive constitution of the ocean.

These first results suggest that the term "management" forms a nodal point of the discourse under review. "Management" is used as a link to combine completely different elements: For instance, one reads in the report of the UN Secretary-General during the sixty-first session of the United Nations General Assembly in 2006 that "the application of ecosystem approaches to ocean management is important for the achievement of sustainable development" or that "the objective of including ecosystem considerations in fisheries management is to contribute to long-term food security and to human development” (United Nations General Assembly, 2006: p. 37). In contrast, the Commission on Sustainable Development "considered ocean issues, in particular waste management and transport” (United Nations General Assembly, 2010: p. 66). For the Committee on International Oceanographic Data and Information Exchange "data management systems that facilitate access, use, and interpretation of the data are of crucial importance" (World Meteorological Organization, 2010: p. 23). Following lexicon entries ${ }^{12}$ the term "management" is used to describe the control and organization of something or to characterize the people in charge of running a business organization. A more detailed examination of the meaning of the term

\footnotetext{
${ }^{12}$ e.g. Cambridge Dictionaries Online, http://dictionary.cambridge.org/de/worterbuch/englisch-deutsch/manage?q=management (access:
} 01.07.2015). 
Table 1. Wordlist of the corpus in total (2002-2012).

\begin{tabular}{|c|c|c|c|c|c|}
\hline $\mathbf{N}$ & Word & Freq. & $\%$ & Texts & $\%$ \\
\hline 1 & MANAGEMENT & 79.766 & 0.31 & 1.857 & 88.09 \\
\hline 2 & SEA & 65.060 & 0.26 & 1.760 & 83.49 \\
\hline 3 & FISHERIES & 64.398 & 0.25 & 1.583 & 75.09 \\
\hline 4 & DATA & 59.901 & 0.24 & 1.618 & 76.76 \\
\hline 5 & FISHING & 56.175 & 0.22 & 1.406 & 66.7 \\
\hline 6 & SPECIES & 51.633 & 0.2 & 1.452 & 68.88 \\
\hline 7 & AREAS & 49.345 & 0.19 & 1.853 & 87.9 \\
\hline 8 & DEVELOPMENT & 44.418 & 0.18 & 1.854 & 87.95 \\
\hline 9 & FISH & 43.688 & 0.17 & 1.423 & 67.5 \\
\hline 10 & INFORMATION & 42.668 & 0.17 & 1.802 & 85.48 \\
\hline \multicolumn{6}{|l|}{$\ldots$} \\
\hline 418 & Sustainability & 6.866 & 0.03 & 1.206 & 57.21 \\
\hline
\end{tabular}

used in the underlying corpus reveals that "management" is being used in a broad spectrum of very different meanings referring to the control and organisation of something (Table 2). This suggests that the term serves as an empty signifier "signifying something that cannot be signified, as empty signifiers are characterized by an indistinct or non-existent signified, i.e. terms that can have different meanings” (Nabers, 2007: p. 22).

After Laclau and Mouffe, an empty signifier enables the different elements of the community to share a special relation of equivalence. It can constitute a new equivalential chain in another discourse and assume a new meaning. Regarding historical-discursive reality as nothing other than a discursive effect, the current discourse on management is the result of articulatory practices that have experienced profound changes as a consequence of various crises responsible for the formation of new discursive connections. As each crisis produces a void of meaning within an existing discourse, "different actors are competing for hegemony by offering their specific systems of narration as a preparatory framework to overcome crisis events and close the open structure” (Nabers, 2007: p. 12). Major crises such as marine pollution, the loss of biodiversity or the impacts of climate change conflict with the sedimented fixation of meaning of unlimited growth and progress and thereby challenge international and national political measures. In this study five confronting chains of equivalence around the empty signifier “management” can be analysed (Figure 2).

\subsection{Management for Supporting Human Activities}

Marine and coastal areas are today experiencing significant changes. The rapid economic growth of the maritime industry has exposed maritime spaces to challenges resulting from increased competition and the dynamics of rapid technical developments in various branches of the maritime economy, especially sea traffic, wind offshore energy, aquaculture, port and harbor developments. Other maritime sectors that are in need to cope with the new conditions include the tourism and fishery industries (Table 2) that both have to adapt to new demands of customers and to an increasingly globalizing competition on the world market. To face these challenges maritime spaces have to adapt and modernize the maritime economy and to find new business and job opportunities, which meet the changed requirements within intensely competitive marine and coastal regions.

\subsection{Management for Conserving Marine and Coastal Resources}

Human activities have a significant impact on loss of biodiversity and an associated loss of ecosystem functionality (AID Environment National Institute for Coastal and Marine Management et al., 2004: p. 30): Fish stocks are overfished or depleted due to IUU-fishing or destructive fishing methods. Coral reefs, the "rainforests of the sea" are in serious decline worldwide due to human impact such as global warming, water acidification and unsustainable resource use (Caras et al., 2009: p. 539). Highly migratory shark populations are threatened with extinction due to targeted or accidental catches in fishing gears (Madina, 2008: p. 3). Many species are endangered by plastic. It is estimated that more than one million birds and 100.000 marine mammals and sea turtles die due to entanglement in or by eating plastic materials (HELCOM, 2009: p. 8). The decline or loss of marine biodiversity can cause a crisis by creating a long-term loss to economics and society. The discourse on conservation of marine 


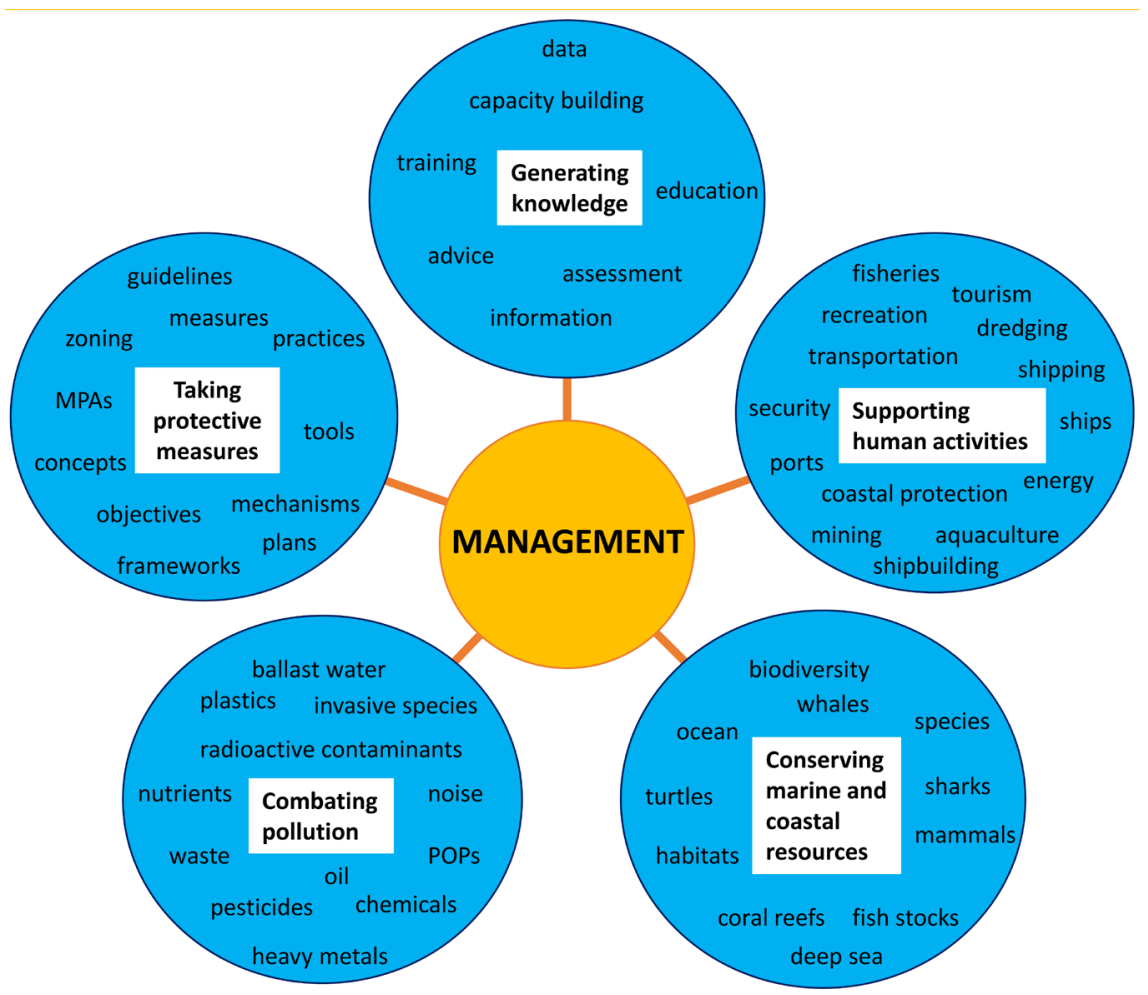

Figure 2. The universal discourse around the floating signifier, management. Source: Own Compilation.

Table 2. Overview of the findings of the evaluation of collocates, co-occurrences and concordances.

(anthropogenic) impact, area, aquaculture, ballast water, biodiversity, chemicals, cetaceans,
climate change, coastal area, coastal protection, conflicts, coral reefs, data(bases), deep sea,
disaster, dredging, eel, energy, exploitation rates, fishery, fisheries, fishing, fish (stocks), fleet,
food, garbage, habitats, heavy metals, human activities, human behaviour, information, krill, leisure,
litter, LMEs, mammals, mangroves, marine ecosystems, mining, MPA's, natural resources, noise,
nutrients, ocean(s), oil, pesticides, plastics, POPs, ports, radioactive contaminants, raw materials,
recreation, (natural, marine) resources, seascape, security, sharks, shipbuilding, ships, shipping,
(invasive, endangered) species, straddling fish stocks, surveillance, tourism, transportation,
turtles, waste, water, watershed, whales, whale-watching, (coastal) zone
Agencies, (public) authorities, business, committee, (local, international, scientific) community,
countries, decision-making, FAO, government, HELCOM, (coastal) initiatives, institutions,
industry, local people, member countries, NAFO, NASCO, organisations, politicians,
private sector, regimes, (local) stakeholder, society, RFMOs, tribal, user groups
Activities, advice, agreements, aims, arrangements, assessment, capacity building, change,
concepts, condition, cooperation, criteria, decisions, economic instruments, education, efforts,
frameworks, guidelines, goals, implementation, information, investment, IUU elimination,
(local) knowledge, law, measures, mechanisms, methods, needs, tools, monitoring, MPAs,
objectives, observation, options, organization, peoples' experience, perspectives, plans (of action),
policies, practices, principles, priorities, procedures, programmes, projects, property rights,
protected areas, quota, recommendations, regulations, response, risk, schemes, solutions,
standards, strategy, structures, systems, targets, tools, training, units, zoning

and coastal ecosystems focuses on questions about the overall status of biodiversity, the rate of loss, where it is being lost, what the causes of decline and loss are, whether conservation actions are achieving desired outcomes and where to concentrate efforts (Conservation International, 2009: p. 51). A new concern in the debate on environmental protection has arisen about the future exploitation of the deep sea resources that are seen as the world's largest reservoir of biological diversity with many highly diverse habitats, such as cold water coral reefs, sea mounts and hydrothermal vents (United Nations Environment Programme, 2006: p. 6). 


\subsection{Management for Combating Pollution}

The discourse on marine pollution can be phrased as a continually re-emerging one that is repeatedly altered by newly emergent crises that bring about decisions. Examples of the past are IMO regulations regarding improved ship design in order to avoid serious tanker accidents. The current discourse focuses on pollution from diffuse sources such as shipping (ballast water, invasive species, oil spills), pollution by chemicals and nutrients from industrial and agricultural effluents, garbage, plastics and noise. The problem of marine invasive species is another example that can trigger a crisis. As maritime traffic has increased fourfold since 1990 (Tournadre, 2014: p. 7931) shipping is one of the main reasons that more and more marine organisms are transported in foreign regions. Unlike chemical pollutants that can degrade over time once established alien aquatic species are permanent (HELCOM, 2009: p. 124) and their impact on ecosystems usually irreversible thus influencing local environmental, economic and social conditions.

\subsection{Management for Taking Protective Measures}

The crises of declining fish stocks and the loss of biodiversity induced many states to agree with international goals to take protective measures. In compliance with international law especially UNCLOS and the Convention on Biological Diversity (CBD) and national law, codes of practices such as the FAO Code of Conduct for Responsible Fisheries, guidelines, concepts and other tools are to be developed. The discourse on this issue focuses on questions in which areas protective measures are needed, what these might be and who should take responsibility (OSPAR Commission, 2008: p. 8). Currently, the establishment of Marine Protected Areas (MPAs) ${ }^{13}$ is much discussed (Sanders et al., 2011: p. 1). In response to the crises of declining fish stocks or the loss of biodiversity many states have agreed to international goals recommending the establishment of MPAs, e.g. within paragraph 32c of the Plan of Implementation of the World Summit on Sustainable Development (WSSD-POI) ${ }^{14}$ or the tenth Conference of the Parties (COP 10) of the Convention on Biological Diversity (CBD) the latter encouraging the member states to "achieve long-term conservation, management and sustainable use of marine resources and coastal habitats, and to effectively manage marine protected areas..." (COP 10 Decision X/29) ${ }^{15}$.

\subsection{Management for Generating Knowledge}

Sustainability of ocean and coasts is not achievable in the absence of capacity (Global Forum on Oceans, Coasts, and Islands, 2008: p. 1) that is defined as "the ability to access and use knowledge to perform a task" (World Bank Institute, 2004: p. 8) or as "the process of changing attitudes and behavior, imparting knowledge and developing skills while maximizing the benefits of participation, exchange of knowledge and ownership" (Ho and Javillonar, 2004: p. 45), the discourse on how to generate knowledge on maritime issues by information, education, training and sharing of experiences has become an increasingly important topic. Capacity building is articulated to be a key instrument for planners, managers, and decision-makers "to enhance planning, implementations, and user compliance” (Editorial, 2002: p. 542) relating to oceans, coastal, and island affairs. The sustainable management of oceans and coasts is articulated to be dependent on capacity building of institutions, society and people as most of the pressing issues such as a more sustainable use of marine resources, compliance with international conventions and agreements, monitoring, control and surveillance to reduce illegal activities, managing conflicts and a more effective and credible leadership in ocean affairs are articulated to be not achievable without improving capacity (Global Forum on Oceans, Coasts, and Islands, 2008: pp. 1-2).

\subsection{Summary}

These results further reveal the complexity of the discourse on ocean affairs. While climate change depends on global warming, the degradation of marine ecosystems can be phrased as a crisis of the social, a crisis of the structure of sedimented and experienced practices that have arisen through the existence of a plurality of stakeholders in different policy fields (fisheries, climate, environmental, agricultural, energy and social) that articulate many perceptions of problems, requirements and practices.

\footnotetext{
${ }^{13}$ The IUCN defines a protected area in its 2008 Guidelines as “.... clearly defined geographical space, recognized, dedicated and managed, through legal or other effective means, to achieve the long-term conservation of nature with associated ecosystem services and cultural values" (Day et al., 2012: p. 9).

${ }^{14} \mathrm{Cf}$. http://www.un.org/esa/sustdev/documents/WSSD POI_PD/English/WSSD PlanImpl.pdf (20.05.2015).

${ }^{15}$ Cf. Marine and Coastal Biodiversity, https://www.cbd.int/decision/cop/?id=12295 (20.05.2015).
} 


\section{The Social Construction of Sustainability in Ocean Affairs}

The previous empirical findings indicate that the discourse on ocean affairs is mainly concerned with a variety of types of ocean management whereas the term sustainability is not apparent under the most frequently named phrases (Table 1). The calculation of the word cloud for sustainability (Figure 3) with the function Concord of WordSmith provides a first impression of how the term is understood within the discourse. What is noticeable is-besides "sustainability”, "sustainable” and "development”-the frequency of the adjectives "social”, "economic" and "environmental" that refers to the three-dimensional model and confirms what has become the core of mainstream sustainability thinking. However, this simple figure shows an imbalance between the three dimensions that are often illustrated as three pillars or overlapping circles of the same size (e.g. Adams, 2006: p. 2). In ocean affairs, the economic dimension has the highest frequency, followed by the environmental and then the social dimension (Figure 4). Another striking feature is the high frequency of "resources" (Figure 3) indicating the importance of marine resources ("stocks", "fish”, “diversity”) and "ecosystem” services. The terms "future", "long”, "term” relate to the Brundtland definition taking into account the needs of future generations. Further notions such as "concept”, "governance”, "people” or "poverty” display a picture of the current discourse on sustainability that covers a complex range of very divergent ideas of a debate that dates back more than 40 years: The Brundtland Commission made an explicit linkage between environment and development issues and emphasized that sustainability cannot successfully be achieved without addressing the problem of poverty (Robinson, 2004: p. 370). The first Rio conference considered sustainability as a requirement to address global environmental problems, loss of biodiversity and resource depletion, and climate change (Adams, 2006: p. 3). The World Summit on Sustainable Development emphasized poverty eradication again, after the United Nations Millennium Summit had agreed upon poverty alleviation as the first of eight Millennium Development Goals. In the wake of these developments, the "phrase sustainable development" began to cover a complex range of very divergent ideas ${ }^{16}$.

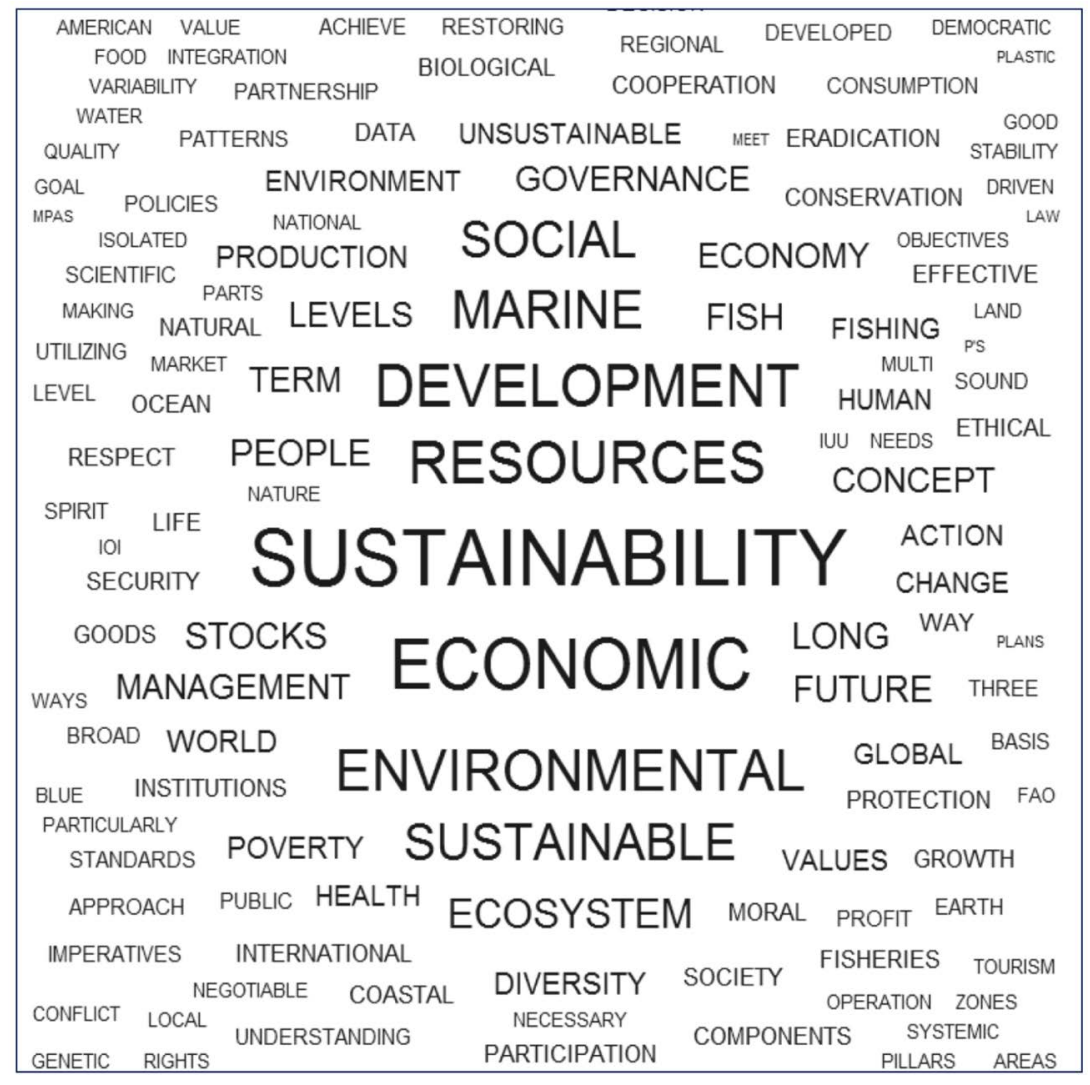

Figure 3. Word cloud for sustainability. Source: Own Compilation.

\footnotetext{
${ }^{16}$ Ibid.
} 


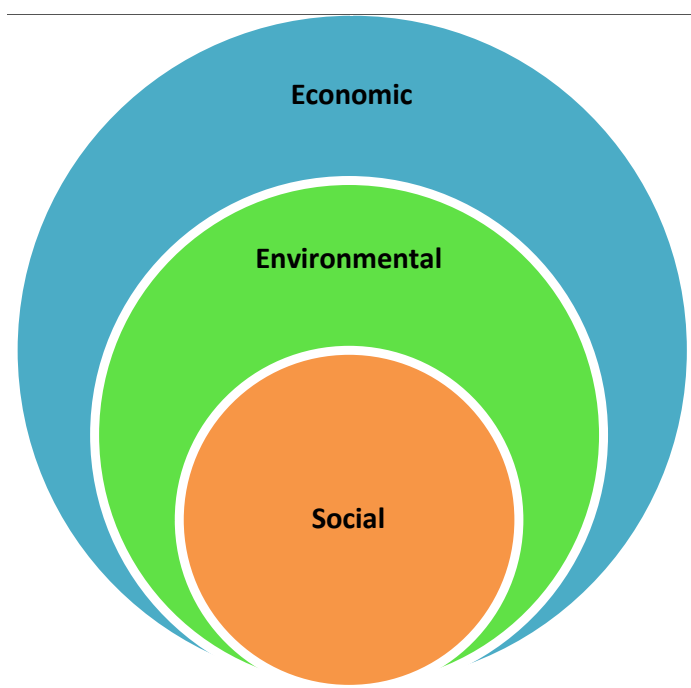

Figure 4. Dimensions of sustainability as concentric circles. Source: Own Compilation.

In order to gain a deeper insight into how the term is used in ocean affairs, concordances, collocations and cooccurrences of the terms "sustainability" and "sustainable development" were computed with Concord. The aim was to answer some basic questions (Table 3): What is to be sustained, for whom/what and how?

The analysis reveals the high complexity of the term that is used to address extremely competing and mutually exclusive targets in some cases: e.g. economic development of "coral trade industry" and "reef fisheries" contra the conservation of "corals", "dredging" contra the protection of "deep sea resources" or "fishing practices" and "fish products" contra the conservation of "fish stocks". While maritime "industry growth" e.g. in the transportation, fisheries and tourism sector can contribute to "human wellbeing" and "benefits", and support "livelihoods", it is highly questionable if this can be achieved without further environmental degradation. This result thus confirms the fundamental criticism in the literature (e.g. Robinson, 2004: p. 370) that it was a deeply flawed proposal to define development primarily as economic growth as this demands an attempt to reconcile two incommensurable areas: development and growth on the one side and ecological sustainability on the other side $^{17}$. It can also be argued that the proposals of how to achieve sustainability in the societal sector (Table 3) e.g. by "compromising human well-being", "behavior" or "consumption change" may be seen in contrast to the demand for sustainability of human wealth. This analysis reveals that the term is used as part of a much broader definition than that given in encyclopedia entries where it is e.g. defined as "economic development that is conducted without depletion of natural resources" 18 or as "the idea that goods and services should be produced in ways that do not use resources that cannot be replaced and that do not damage the environment" ${ }^{19}$ Instead, the concept provides a framework not only for the conservation of nature but for tackling growing societal challenges such as ensuring food security, energy supply, health and human well-being, whilst simultaneously responding to climate change, marine pollution and the destruction of marine and coastal habitats. It can be phrased as a common goal or bias for development and thus fits well into the group of other great human ideals such as "human rights", "peace" or "freedom", goals, as Clark et al. (2005: p. 17) put it we think more about moving toward than we do about achieving them. This suggests that sustainability functions as an empty signifier framed as a "fluid concept" with "various definitions" that "have emerged over the past two decades" (Drexhage et al., 2010: p. 6). To understand the high complexity of the term it is necessary to address other signifiers, as the meaning of sustainability arises from the difference between a nearly unlimited number of signifiers. Following the "prism"model (Spangenberg, 2002: p. 305) sustainability can be articulated to be based on an economic, environ-

\footnotetext{
${ }^{17}$ The conflict between an ecological and a cost-benefit thinking did not emerge with the definition of the Brundtland Commission but has very deep roots. Already in the $19^{\text {th }}$ century a forester complained that the concept of sustainability can be interpreted in such a way that every ruthless overexploitation is possible (Borggreve, 1888: p. 253).

${ }^{18} \mathrm{Cf}$. Oxford Dictionaries, http://www.oxforddictionaries.com/definition/english/sustainable-development?q=sustainable+development (access 01.07.2015).

${ }^{19}$ Cf. Cambridge Dictionaries, http://dictionary.cambridge.org/de/worterbuch/business-englisch/sustainability (access: 01.07.2015).
} 
Table 3. Overview of the findings of the evaluation of collocates, co-occurrences and concordances.

\begin{tabular}{|c|c|c|c|c|}
\hline & Economic development & Environmental development & Social development & Institutional development \\
\hline 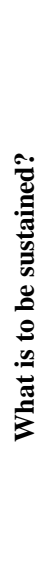 & $\begin{array}{l}\text { - Aquaculture } \\
\text { - Capture fisheries } \\
\text { - Catches/harvests } \\
\text { - Commercial and } \\
\text { recreational industries } \\
\text { - Coral trade industry } \\
\text { - Dredging } \\
\text { - Exploitation } \\
\text { - Mining } \\
\text { - Small scale farms } \\
\text { - Fishing practices } \\
\text { - Fish products } \\
\text { - Industry growth } \\
\text { - Krill fishery } \\
\text { - Maritime transport } \\
\text { - Reef fisheries } \\
\text { - Small scale fisheries } \\
\text { - Tourism industry }\end{array}$ & $\begin{array}{l}\text { - Arcti/Antarctic ecosystems } \\
\text { Biodiversity } \\
\text { - Bycatch } \\
\text { - Commons } \\
\text { - Corals } \\
\text { - Coastal systems } \\
\text { - Deep sea resources } \\
\text { - Fish stocks } \\
\text { - Food web } \\
\text { - Islands } \\
\text { - Living marine resources } \\
\text { - Marine ecosystems } \\
\text { - Marine habitats } \\
\text { - Marine species } \\
\text { - Pelagic fisheries } \\
\text { - Shellfish }\end{array}$ & $\begin{array}{l}\text { - (long-term) benefits } \\
\text { - Community development } \\
\text { - Employment } \\
\text { - Food security } \\
\text { - Health } \\
\text { - Human well-being } \\
\text { - Livelihoods }\end{array}$ & $\begin{array}{l}\text { - Data/Data collection } \\
\text { - Enforcement measures } \\
\text { - Financial resources } \\
\text { - Programmes } \\
\text { (GOOS, IODE, JCOMM) } \\
\text { - Project funding } \\
\text { - Observing systems } \\
\text { - Ocean fertilization } \\
\text { - Order, peace, security in the } \\
\text { ocean } \\
\text { - Organisations/ } \\
\text {-initiatives/facilities/ } \\
\text { services } \\
\text { - RAMSAR sites } \\
\text { - World Maritime University }\end{array}$ \\
\hline 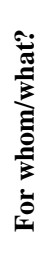 & $\begin{array}{l}\text { - Aquaculture segments } \\
\text { - Community gains } \\
\text { - Fisheries sector } \\
\text { - Economic gains } \\
\text { - Tourism }\end{array}$ & $\begin{array}{l}\text { - Biodiversity } \\
\text { - Coastal zone systems } \\
\text { - Europe’s coastal areas } \\
\text { - Marine ecosystems } \\
\text { - Marine resources } \\
\text { - LMEs } \\
\text { - Species } \\
\text { - Stocks }\end{array}$ & $\begin{array}{l}\text { - Affected populations } \\
\text { - Anglers } \\
\text { - Communities of users } \\
\text { - European citizens } \\
\text { - Fishery communities } \\
\text { - Future generations } \\
\text { - Human purposes }\end{array}$ & $\begin{array}{l}\text { - Observation systems } \\
\text { - Ocean Biogeographic } \\
\text { Information System (OBIS) }\end{array}$ \\
\hline$\tilde{3}$ & $\begin{array}{l}\text { - Decision-making } \\
\text { in the transport sector } \\
\text { - Economic gains } \\
\text { - Environmental considerations } \\
\text { in business } \\
\text { - High priority on environmental } \\
\text { considerations in ports business } \\
\text { - ICM } \\
\text { - Linking individual or group } \\
\text { demands to ecological capacity } \\
\text { - Long-term research } \\
\text { partnerships and collaboration } \\
\text { - MSP } \\
\text { - Responsible tourism business }\end{array}$ & $\begin{array}{l}\text { - Assessments of ecological } \\
\text { status } \\
\text { - Climate policy } \\
\text { - ICM } \\
\text { - Maintaining the capacity of } \\
\text { aquatic ecosystems } \\
\text { - Long-term research } \\
\text { partnerships and } \\
\text { collaboration } \\
\text { - MSP } \\
\text { - Observing systems } \\
\text { - Pollution and waste } \\
\text { - Science } \\
\text { - Synthesizing the } \\
\text { ecosystem science } \\
\text { in various user-friendly ways }\end{array}$ & $\begin{array}{l}\text { - Behaviour change } \\
\text { - Capacity building } \\
\text { - Compromising human } \\
\text { well-being } \\
\text { - Consumption change } \\
\text { - Critically analysing } \\
\text { proposed mechanisms for } \\
\text { and pathways to } \\
\text { sustainable societies } \\
\text { Development } \\
\text { - Education } \\
\text { - Ethics } \\
\text { - Linking individual or } \\
\text { group demands to } \\
\text { ecological capacity } \\
\text { - Mechanisms for and } \\
\text { pathways to sustainable } \\
\text { societies }\end{array}$ & $\begin{array}{l}\text {-Control and management of } \\
\text { ships } \\
\text { - Governance } \\
\text { - Implementation of existing law } \\
\text { - Initiatives by governments } \\
\text { - Integrating economic, social } \\
\text { and environmental } \\
\text { considerations in } \\
\text { decision-making } \\
\text { - Involved stakeholders } \\
\text { - Legislation } \\
\text { - Monitoring } \\
\text { - Norms } \\
\text { - Organisations } \\
\text { - Providing timely and } \\
\text { useful information to } \\
\text { decision makers } \\
\text { - Restricting rights } \\
\text { - Rules } \\
\text { - Surveillance }\end{array}$ \\
\hline
\end{tabular}

mental, societal and institutional dimension (Bodiguel et al., 2009: p. 45; United Nations General Assembly, 2005: p. 47). Thus, it can be said that sustainability links and stabilizes four separate discourses that constitute different chains of equivalence, referring to other specific meanings but are at the same time linked to the common denominator by the logic of equivalence (Figure 5). This indicates that the term representing a multitude of differential elements has been emptied of its meaning.

\subsection{The Discourse on Social Development}

To achieve a sustainable society, action is stated as being needed at all levels of society. The nodal point social development partially fixes the meaning of a chain of moments that can roughly be distinguished according to the purpose of each signifier:

- to ensure and improve quality of life and standard of living (food security, health, employment, wellbeing, ...), 


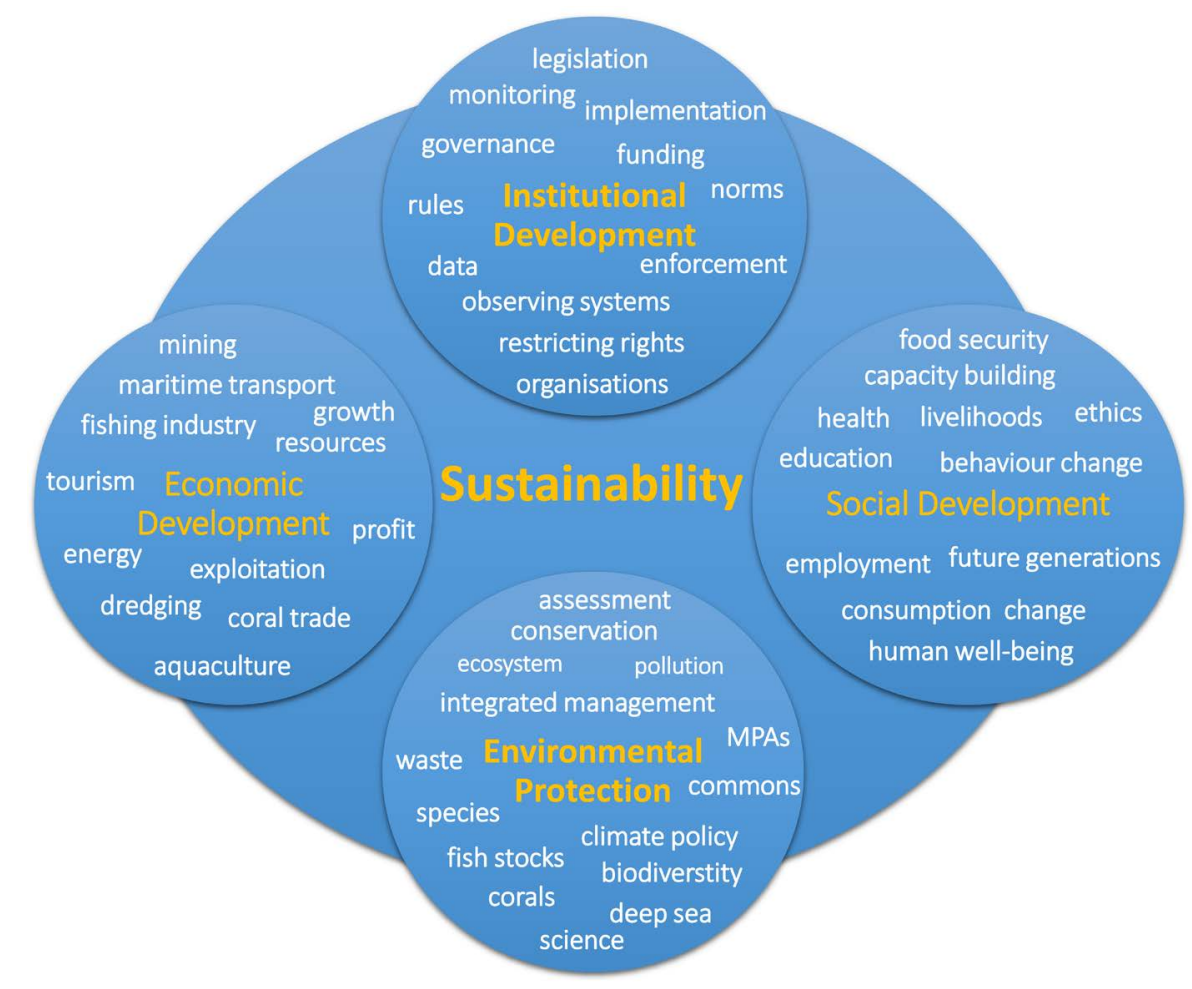

Figure 5. Sustainability stabilizes four different discourses. Source: Own compilation.

- to combat poverty and support human rights and gender equality that are seen as major obstacles to achieve sustainability,

- to bring about a change toward a more sustainable way of living (behavior and consumption change, education and capacity building,...) and ethic referring to social justice and future generations.

While securing food, water, energy, health, education and environment traditionally encompasses government activities the trade-off between reducing poverty and protecting the environment as a central and critical issue on the way to sustainable development was first formulated by the UN World Commission on Environment and Development in the mid-1980s. Subsequently, new discourses emerged referring to the nexus of sustainable development and poverty alleviation, human rights and gender equality ${ }^{20}$. In particular, the Johannesburg Declaration (World Summit on Sustainable Development, 2002: p. 2) and the Rio + 20 outcome document (United Nations General Assembly, 2012: p. 9) stress the importance of gender equality in the way how e.g. fishing is defined and fisheries is understood. Opposing them a major shift in gender roles in the fisheries sector is observed with "the traditional roles redefined to exclude or marginalize women, in a sort of 'masculinization' of the sector, which thrives on profit making at the expense of long-term sustainability" (International Collective in Support of Fishworkers, 2001: p. 146). The "invisibility" of women in the fisheries sector was phrased as to impact decision-making bodies and prevent to influence the development of fisheries towards more sustainability as fish is phrased as "community", "family", "food", "history and future”, "business and culture”, "power and welfare”, "conflict and peace", "sorrow and happiness", "rights and obligations" (International Collective in Support of Fishworkers, 2004: p. 83).

Other moments of the discourse refer to the systemic change in our economic values behavior that cannot any longer be based on "the market value and profit margins of production and exploitation that are driven by greed" (Behnam, 2012: p. 4). The issue how to encourage people to live in a more sustainable way in their daily life is articulated to be a main challenge. According to this understanding education "not only of people but entire nations" as well as capacity building are phrased to play an important role to acquire the right competences and at-

${ }^{20}$ Cf. Rio Declaration on Environment and Development of 1992 (Principle 5), FAO Code of Conduct for Responsible Fisheries of 1995 (Art 6), The Johannesburg Declaration on Sustainable Development of 2002 (Section 11), Outcome document: “The Future we Want” of 2012 (section 2) and the UN 2030 Agenda for Sustainable Development of 2015 (Preamble). 
titudes to progress the "vision of sustainable development and a sustainable future” (Pacem in Maribus, 2007: p. 216). The last group of moments relate to a discourse on social responsibility taking into account the rights of the present and future generations.

\subsection{The Discourse on Environmental Protection}

The meaning of environmental protection is constituted within a chain of moments that can be assigned to three questions:

- What is to be protected (biodiversity, deep sea, ecosystem, commons, corals, fish stocks, pollution and waste...)?

- What is needed (assessment of the status, science,...)?

- What are the methods (integrated management, MPAs, climate policy,...)?

A first discourse on the need of environmental protection came to exist in 1902 when the International Council for the Exploration of the Sea (ICES) was established when the decline of fish stocks in the Baltic Sea and the North Atlantic became a reason of concern. Since then, a broad range of resource and environmental challenges such as the decrease in biodiversity, overexploitation of fish stocks, ongoing pollution of marine and coastal areas and the impact of climate change on the ocean, especially the problem of acidification have triggered the emergence of new discourses. To face these challenges science and scientific methods are important signifiers. With its currents, ice masses, living and non-living organisms, the ocean forms an extremely complex system whose marine and coastal processes can only be understood by science and sophisticated technologies. The understanding of marine and coastal processes and resources is formulated as an "essential requirement for ocean management and sustainable development that demands the routine sampling of data and information from all parts of the world" (Global Coral Reef Monitoring Network, 2002: p. 3). In this context the signifier of environmental impact assessment is another relevant signifier as the means still do not exist to assess the impact of human activities on marine ecosystems. After UNEP published the "Assessment of Assessment" (AoA) in 2009 the first cycle of the so-called Regular Process (2010-2014) for global reporting and assessment of the ocean, the "World Ocean Assessment" is expected to be completed in 2015. The discourse on management for protective measures such as the approaches of ICZM, the creation of MPAs or marine spatial planning (MSP) are further relevant signifiers.

\subsection{The Discourse on Economic Development}

Today, a substantial part of the world economy is wholly dependent on ocean resources, services and space. Thus the ocean is to a considerable degree contributing to human wealth. In the endeavor to further maximize human well-being economic growth is articulated as being part of the solution. The hunger for wealth represents an important signifier that constitutes the discourse of economic development in diverse economic sectors such as aquaculture, coral trade, energy, fishing, mining, transportation and the tourism and recreational industry. This corresponds with the view of governments and businesses that economic growth is necessary to "raise living standards globally and break the link between poverty and environmental degradation" (Drexhage et al., 2010: p. 10). The European seas and oceans for example are phrased to be of "major strategic importance to the economic and social development of Europe as European maritime regions account for $40 \%$ of Europe's Gross Domestic Product (GDP) and maritime related activities provide direct employment to an estimated 3.5 million citizens" (European Science Foundation, 2006: p. 9). The prerequisite for economic growth is the existence of a steady flow of resources that is here seen as a further signifier. While land resources are becoming more scarce due to the demands of an increasing world population, the exploitation of marine resources increases in importance. As this is only possible by means of science and modern marine technologies these factors constitute two other relevant signifiers that structure the discourse of economic development. The struggle for marine resources and the utilization of ocean space can also be phrased as a permanent source of conflicts. These affect fisheries and energy industry, shipping, military activities, territorial claims, tourism and conservation. Thus the signifier conflict forms a separate discourse that constitutes a specific chain of equivalence.

\subsection{The Discourse on Institutional Development}

Achieving sustainable development in ocean affairs especially in areas beyond national jurisdiction requires good governance practices, particularly the implementation and enforcement of international law and agree- 
ments. The current discourse on institutionalization fixes the meaning of a chain of signifiers (legislation, rules, norms, implementation, funding...) that refer to the expansion and organization of governmental institutions and structures related to marine affairs. Ocean governance is of global nature and can be articulated as a common effort of numerous institutions and different actors that are involved in a complex and multi-scaled process representing different and partly competing subject positions (Figure 6). This complexity, referred to as "multilevel governance" within political science, requires a system and a capacity to deal with "interactions among biophysical and human drivers" and an ability "to monitor changes of the marine environment closely, adjust existing practices to changing circumstances, and cope with relatively high levels of uncertainty” (Young et al., 2007: p. 22). This suggests that ocean governance functions as an empty signifier that constitutes a political community involved in the process of institutionalization.

While various measures and initiatives on an international and regional level have been taken to conserve and protect the marine environment-for example in the Baltic Sea or in the $\mathrm{EU}^{21}$ - there is still a lack of governance structures referring to the world ocean. Instead, the high seas are ruled by a more or less dense set of international conventions, UN institutions, inter-governmental and non-governmental organizations (Figure 6) whereby most of them have only emerged during the last decades (e.g. Haas et al., 1993: pp. 33-182; Skjærseth, 2002b: pp. 65-86; Wang, 2004: p. 58).

Since 1982 the world has a kind of a "constitution for the seas" (WBGU, 2013: p. 2) with the United Nations Convention on the Law of the Sea (UNCLOS), and thus a "primary instrument of governance for the seas" (Maribus, 2010: p. 198). Though in the last three decades since the adoption of UNCLOS a variety of protocols, conventions, binding and non-binding multilateral agreements and guidelines in support of UNCLOS (Behnam, 2012: p. 8) have been taken at international, regional and national levels, the existing system of ocean governance has failed so far:

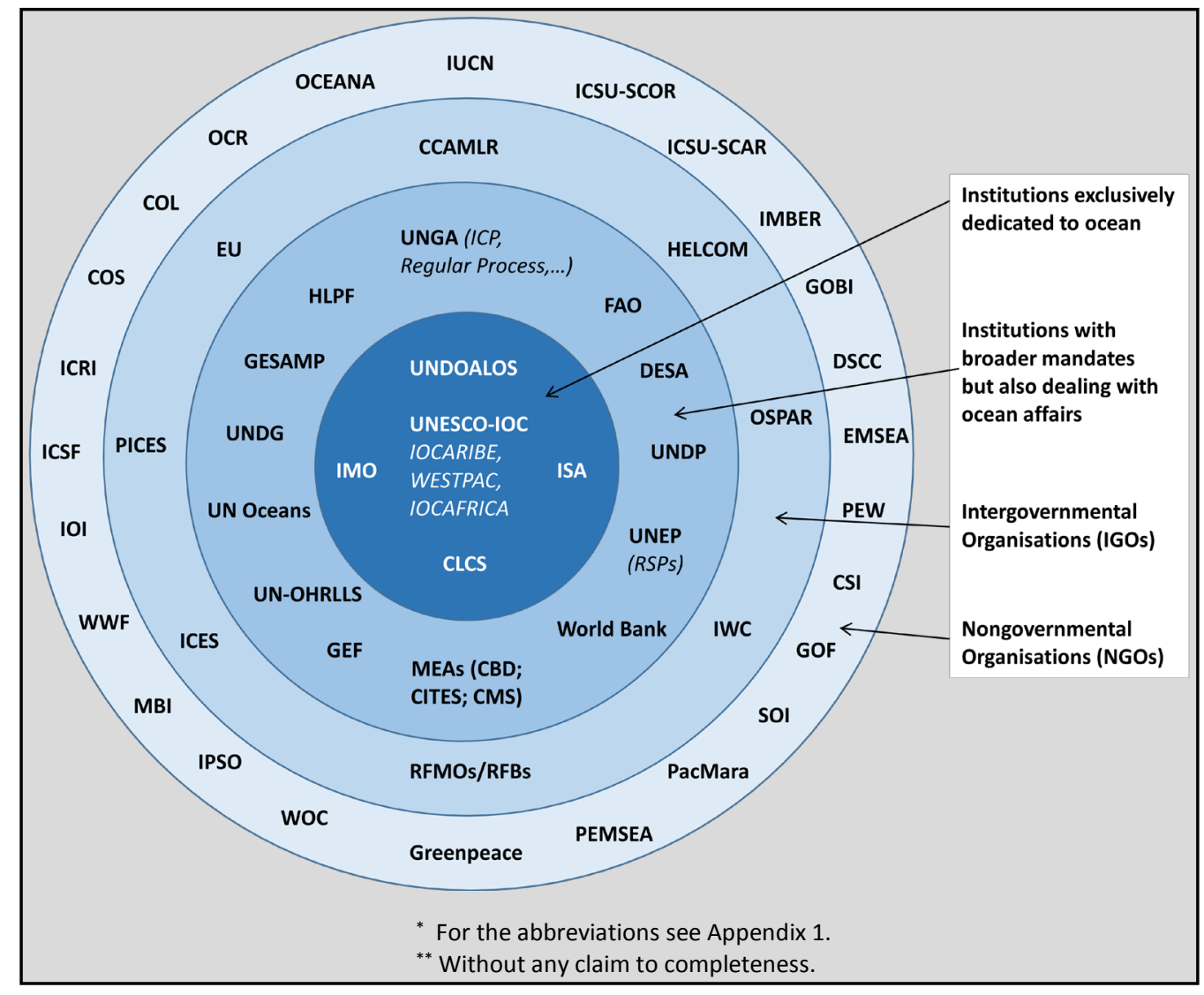

Figure 6. Ocean community. Source: Own compilation.

\footnotetext{
${ }^{21}$ e.g. the Baltic Sea Action Plan (2007) or the European maritime strategy framework directive (2006).
} 
- Since UNCLOS has already been adopted in 1982 new scientific findings or issues relating to e.g. wreck removal, geoengineering or marine genetic resources are missing or not fully addressed and have to be supplemented by additional treaties.

- The treaty contains some unresolved systemic issues e.g. regarding the scope of application of the common heritage principle or the missing protection of the water column on the high seas that falls under the regime of the freedom of the high seas thus allowing flags-of-convenience to plunder this area with impunity by ignoring any laws or ethical demands of sustainable development (Behnam, ibid).

- UNCLOS and existing environmental regulations lack implementation through enforcement and compliance though for more than two decades the international community has recognized the huge importance of a healthy ocean for human well-being and undertaken technical and organizational measures to support and strengthen ocean governance ${ }^{22}$ (FAO Committee on Fisheries, 2012: p. 2).

- Responsible authorities are hardly able to sanction misconduct or non-compliance of contracting parties.

- Ocean governance still operates too inefficiently. While many institutions and initiatives are involved in ocean issues there is a need for a more integrated management to avoid parallel and uncoordinated activities $^{23}$.

- There are spatial and regulatory gaps e.g. encompassing species-specific or area-specific closures under the Regional Fisheries Management Organisations (RFMOs) or Special Areas and Particularly Sensitive Sea Areas (PSSAs) protected from damage by international maritime activities under the International Maritime Organisation (IMO) (UNEP World Conservation Monitoring Centre, 2008: p. 105).

\subsection{Summary}

These deficits of governance together with the rapid pace of technological progress in maritime economy have further aggravated ocean health. Despite well intentioned approaches e.g. within the framework of the Rio process and the support of many stakeholders, the international community has failed the target "to live with the ocean and from the ocean in a sustainable relationship” (Behnam, 2012: p. 8). As the implementation of sustainability strongly depends on ocean governance major changes to UNCLOS are articulated as being necessary to create a "sustainable stewardship of the oceans" (WBGU, 2013: p. 3) e.g. measures based on the precautionary principle or the ecosystem approach. However, such an initiative is articulated as having little chance of success due to the conflicting perspectives of implementing sustainability and political feasibility (United Nations General Assembly, 2012: pp. 23-24, WBGU, 2013: p. 3).

This analysis demonstrates that the use of the above mentioned other signifiers is necessary to define the signifier sustainability in all its complexity. The meaning of a term does not arise from the concept itself but is the result of its difference from an almost endless number of signifiers. The relational structure thereby prevents a universal and timeless "truth". Instead, sustainability plays the role by representing a precarious truth to which the other signifiers relate. While the chain of equivalence (cf. Figure 5) constantly changes over time sustainability itself remains relatively stable. In conclusion, it can be argued that the poststructuralist approach of Laclau and Mouffe provides a method to explain the ambiguity of the concept of sustainability as well as the practice of institutions in rephrasing existing objectives and activities in compliance with sustainability without really changing their business as usual approach.

\section{Conclusion}

This study has shown that the discourse on ocean affairs is mainly about the empty signifier "management", which constitutes new chains of equivalence in five antagonistic discourses around the signifiers "supporting human activities, generating knowledge, protecting and conserving marine and coastal resources, combating pollution and taking protective measures". Through the logic of equivalence, "management" assumes new meanings and generates new identities. The hegemonic process around the empty signifier "management" offers an example of this discursive struggle within the current discourse on ocean affairs that can be explained as articulatory practices adopted to overcome major crises caused e.g. by marine pollution or the loss of biodiversity. The degradation of marine and coastal ecosystems can be formulated as a crisis of the social, a crisis of the structure of sedimented and experienced practices expressed between different subject positions that articulate many perceptions of problems, requirements and practices and where a hegemonic consensus has to be achieved

\footnotetext{
${ }^{22}$ e.g. in the framework of UNCLOS, the Rio process and IMO conventions.

${ }^{23}$ Ibid 8.
} 
that specifies the production and consumption patterns of the world economy. This discursive struggle together with the sedimented fixations of meaning of economic growth, progress and removals of barriers to trade challenge international and national political measures adopted to achieve a more sustainable way of living.

The lexicometric analysis of "sustainability" confirmed the traditional three dimensional structures comprising of economic, social and environmental dimensions supplemented by an institutional one. It is argued that the concept can be framed as a metaphor for a solution to face the most pressing challenges of the world such as maintaining the healthy functioning of the Earth's ecosystems, changing the unsustainable production and consumption patterns, poverty eradication or social justice. These traditional signifiers as well as ocean-related ones such as fisheries, marine conservation, science or ocean governance can be identified as key signifiers that make it possible to adopt a subject position on a certain theme. As there are many other subject positions available with which people can identify and adopt a certain political or social position the discourse on sustainability as a product of ongoing articulation and re-articulation processes depicts a discursive struggle where identification with a certain signifier simultaneously means the exclusion of others. Though the "other" blocks one's own position it is the "other" that is the precondition for the existence of a certain position. On the one side this flexibility provides the basis for the general acceptance of the concept while on the other side this enables different subjects to use it for their own benefits. This could explain why no serious action is taken on the ground despite there being a huge global constituency that cares deeply about sustainability. It can be said that the concept is widely accepted in theory but does not work successfully in practice.

Comparing the hegemonic discourse on sustainability at the UN level with that on climate change, Methmann, (2010: p. 355) calls the discourse on sustainability a "passive revolution" that aims at "preventing any deeper or even counter-hegemonic social transformation.” In contrast, climate change constructed as a global crisis and a security issue endangering world peace has triggered a series of practices such as the Kyoto Protocol or the assessment reports of the Intergovernmental Panel on Climate Change (IPCC). This comparison underlines the great importance of how specific issues are socially constructed. Sustainability is far from being understood as a crisis that could trigger new policy interests at the United Nations. Instead, it is a positively connotated term since it is associated with protection, conservation, durability and stability. This positive construction is mainly used "as a way to paint environmentally destructive practices green" (Greenpeace, 2010) while environmental and social concerns are of subordinate importance. The present analysis of the discourse of ocean affairs has confirmed this imbalance between the four dimensions of sustainability. This mismatch can be identified as being responsible for the fact that marine and coastal ecosystems and spaces are used unsustainably and are being harmed with little public awareness and too little preventative action being taken.

Finally, the question remains whether it makes sense to adhere to the concept of sustainability in ocean affairs. There are several reasons why the concept is still of importance:

- Sustainability can be phrased as an "established brand" that is widely recognized and still "expresses some core values to a wide audience" (Adams, 2006: p. 10).

- It is being discussed in politics, science, business, society and the media in many parts of the world.

- There is growing awareness throughout the world that human well-being strongly depends on the quality of the environment and ecosystem services. Sustainable development is expressed as "a key concept that is valid for both bio-ecological aspects and human dimensions" (FAO, 2012: p. 91).

- The concept of sustainability is an important element of several significant documents of the Rio process and the recently adopted UN post-2015 development agenda.

Hence, it can be concluded that the broad concept and its underlying benefits (Sweeney and Bruce, 2007: p. 221) have been accepted by a huge constituency around the world that "cares deeply and talks about sustainability" (Drexhage et al., 2010: p. 2). However, though progress has been made towards the implementation of sustainability much too little has been done to change human behavior that still relies excessively on fossil fuels, consumes too many resources and produces too much waste (Sweeney and Bruce, 2007: p. 215). The main challenge for sustainable development is the question how people can be empowered and mobilized to make sustainable choices.

Furthermore, other forms of knowledge than research insights such as artisanal fisheries, indigenous and local communities may vary from place to place. It is for this reason that it seems to be more promising that coastal or islands communities develop and define their own targets to approach sustainability. This means to deal with the complexity of marine ecosystems and to make decisions "under conditions of deep contingency and uncertainty" ${ }^{\text {"2 }}$. This understanding focuses on sustainable development to be less a state but more a direction that demands continuous adaptation to the changing environment. In this context, the National Research Council, ${ }^{24}$ Ibid. 
(1999: p. 48) referred to sustainability “as a process of social learning and adaptive response amidst turbulence and surprise". The change of focus from "knowing” to "learning” lends to a greater importance of education and capacity building to acquire the right competences and attitudes to meet the challenges in implementing sustainable approaches. This comprises the implementation of the concept by various means and levels: For example, on the institutional level it is necessary to implement UNCLOS, to enable the transfer of marine science and technology to ensure that all States are able to implement the law of the sea, to provide financial assistance, to promote partnerships and the participation of all States in global and regional fora and to address the needs of all language regions. On the societal level there is a need to enhance the knowledge and awareness about the value of the ocean among decision makers, the media and the public, to develop criteria and standards for the management, conservation and use of marine resources and areas as well as to support school programmes and public outreach. Finally, on the individual level it is vital to educate and train individuals for instance to know how to access, use, develop and process marine observation data.

These measures will not solve all the big problems of sustainability as mentioned above but show a way in the right direction not only to raise awareness of sustainability but also to train people in practice and to enable their participation in the full implementation process of sustainability. While in the last two decades most of the topdown measures to implement the concept of sustainability have failed to mitigate the degradation of the marine environment, bottom-up approaches seem to be more promising to strengthen regional and local organisations, industries and individuals who are involved in the process of sustainability and in the end do the job.

\section{Acknowledgements}

First of all I am thankful to the Cluster of Excellence "The Future Ocean” at the University of Kiel for the financial support of this research. I would particularly like to express my sincere gratitude to my advisor Prof. Dr. Dirk Nabers for his aspiring guidance, invaluable constructive criticism and friendly advice during this research work. Furthermore, I would like to thank Jan Zeeman for his insightful comments.

\section{References}

Adams, W. M. (2006). The Future of Sustainability: Re-Thinking Environment and Development in the Twenty-First Century. The World Conservation Union. http://cmsdata.iucn.org/downloads/iucn future of sustanability.pdf

AID Environment National Institute for Coastal and Marine Management/Rijksinstituut voor Kust en Zee (RIKZ), Coastal Zone Management Centre, the Netherlands (2004). Integrated Marine and Coastal Area Management (IMCAM) Approaches for Implementing the Convention on Biological Diversity. Montreal: Secretariat of the Convention on Biological Diversity, CBD Technical Series No. 14.

Atkinson, G., Dubourg, R., Hamilton, K., Munasinghe, M., Pearce, D., \& Young, C. (1997). Measuring Sustainable Development: Macroeconomics and the Environment. Cheltenham: Edward Elgar Publishing Limited.

Baumgärtner, S., \& Quaas, M. F. (2010). What Is Sustainability Economics? Ecological Economics, 69, 445-450.

http://dx.doi.org/10.1016/j.ecolecon.2009.11.019

Behnam, A. (2012). From UNCLOS to Rio + 20 and the Oceans Compact. International Ocean Institute. http://ioinst.org

Belsey, C. (2002). Poststructuralism. A Very Short Introduction. Oxford: Oxford University Press. http://dx.doi.org/10.1093/actrade/9780192801807.001.0001

Bijma, J., Pörtner, H. O., Yesson, C., \& Rogers, A. D. (2013). Climate Change and the Oceans-What Does the Future Hold? Marine Pollution Bulletin, 74, 495-505. http://dx.doi.org/10.1016/j.marpolbul.2013.07.022

Bodiguel, C., Gréboval, D., \& Maguire, J. J. (Eds.) (2009). Factors of Unsustainability and Overexploitation in Marine Fisheries-Views from the Southern Mediterranean, West Africa, Southeast Asia and the Caribbean. FAO Fisheries and Aquaculture Circular, No. 1037.

Borggreve, B. R. A. (1888). Die Forstabschätzung. Berlin: P. Parey.

Brandt, W. (1980). Das Überleben sichern. Gemeinsame Interessen der Industrie- und Entwicklungsländer. Bericht der Nord-Süd-Kommission/Independent Commission on International Development Issues, Köln: Kiepenheuer \& Witsch.

Caras, T., \& Pasternak, Z. (2009). Long-Term Environmental Impact of Coral Mining at the Wakatobi Marine Park. Indonesia, Ocean \& Coastal Management, 52, 539-544. http://dx.doi.org/10.1016/j.ocecoaman.2009.08.006

Clark, M. R., Tittensor, D., Rogers, A. D., Brewin, P., Schlacher, T., Rowden, A., Stocks, K., \& Consalvey, M. (2006). Seamounts, Deep-sea Corals and Fisheries: Vulnerability of Deep-Sea Corals to Fishing on Seamounts beyond Areas of National Jurisdiction. Cambridge: UNEPWCMC. 
Clark, W. C., Crutzen, P. J., \& Schellnhuber, H. J. (2005). Science for Global Sustainability: Toward a New Paradigm. CID Working Paper No. 120, Cambridge, MA: Science, Environment and Development Group, Center for International Development, Harvard University.

Conservation International (2009). Proceedings of the 2008 Annual Seascapes Strategy Workshop, Kota Kinabalu, 11-13 December 2008. Arlington, VA: Conservation International.

Costanza, R. (1999). The Ecological, Economic, and Social Importance of the Oceans. Ecological Economics, 31, $199-213$. http://dx.doi.org/10.1016/S0921-8009(99)00079-8

Crutzen, P. J. (2002). Geology of Mankind. Nature, 415, 23. http://dx.doi.org/10.1038/415023a

Culler, J. (1986). Ferdinand de Saussure (Second Revised ed.). Ithaca: Cornell University Press.

Daly, H. E., \& Cobb, J. B. (1989). For the Common Good. Boston, MA: Beacon Press.

Day, J., Dudley, N., Hockings, M., Holmes, G., Laffoley, D., Stolton, S., \& Wells, S. (2012). Guidelines for Applying the IUCN Protected Area Management Categories to Marine Protected Areas. Gland: IUCN.

Doney, S. C. (2009). Ocean Acidification: The Other $\mathrm{CO}_{2}$ Problem. Annual Review of Marine Science, 1, 169-192. http://dx.doi.org/10.1146/annurev.marine.010908.163834

Doney, S. C., Ruckelshaus, M., Duffy, J. E., Barry, J. P., Chan, F., English, C. A., Galindo, H. M., Grebmeier, J. M., Hollowed, A. B., Knowlton, N., Polovina, J., Rabalais, N. N., Sydeman, W. J., \& Talley, L. D. (2012). Climate Change Impacts on Marine Ecosystems. Annual Review of Marine Science, 4, 11-37.

http://dx.doi.org/10.1146/annurev-marine-041911-111611

Drexhage, J., \& Murphy, D. (2010). Sustainable Development: From Brundtland to Rio 2012. Background Paper Prepared for Consideration by the High Level Panel on Global Sustainability at Its First Meeting, 19 September 2010, UN Headquarters, New York.

http://www.un.org/wcm/webdav/site/climatechange/shared/gsp/docs/GSP1-6 Background\%20on\%20Sustainable\%20Dev $\underline{\text { t.pdf }}$

Editorial (2002). Introduction to the Special Issue on Capacity Building. From the 1992 Earth Summit to the 2002 World Summit on Sustainable Development: Continuing Challenges and New Opportunities for Capacity-Building in Ocean and Coastal Management. Ocean \& Coastal Management, 45, 541-548.

European Science Foundation (2006). Navigating the Future-III. Position Paper 8, Nov. 2006.

FAO Committee on Fisheries (2012). Ocean Governance and the Outcomes of Rio+20. Thirtieth Session Rome, Italy, 9-13 July, COFI/2012/6/Rev.1.

Feely, R. A., Sabine, C. L. S., \& Fabry, V. J. (2006). Carbon Dioxide and Our Ocean Legacy. http://www.pmel.noaa.gov/pubs/PDF/feel2899/feel2899.pdf

Food and Agriculture Organization (1995). Code of Conduct for Responsible Fisheries. Rome: FAO.

Food and Agriculture Organization (2012). The State of World Fisheries and Aquaculture. Opportunities and Challenges. Rome: FAO.

Glasze, G. (2008). Vorschläge zur Operationalisierung der Diskurstheorie von Laclau und Mouffe in einer Triangulation von lexikometrischen und interpretativen Methoden. http://www.ssoar.info/ssoar/handle/document/19112

Glasze, G., \& Mattissek, A. (2009). Handbuch Diskurs und Raum: Theorien und Methoden für die Humangeographie sowie die sozial- und kulturwissenschaftliche Raumforschung. Bielefeld: Transcript Verlag.

Global Coral Reef Monitoring Network (2002). Status of Coral Reefs in East and North Asia: China, Korea, Japan and Taiwan. In C. R. Wilkinson (Ed.), Status of Coral Reefs of the World: 2002 (pp. 153-162). GCRMN Report, Townsville: Australian Institute of Marine Science.

Global Forum on Oceans, Coasts, and Islands (2008). Policy Brief: Strategic Interventions for Developing Capacity to Improve Governance of Oceans, Coasts, and Small Island Developing States over the Period 2008 to 2018.

https://globaloceanforumdotcom.files.wordpress.com/2013/05/capacity-building-pb-april21.pdf

Greenpeace (2010). Introduction to StopGreenwash.org. http://stopgreenwash.org/introduction

Grotius, H. (1609). Mare Liberum. Leiden: Brill.

Guijt, I., \& Moiseev, A. (2001). Resource Kit for Sustainability Assessment. Gland, Switzerland and Cambridge, UK: IUCN. Part A x + 83 pp., Part B viii + 172 pp., Part C iv + 92 pp.

Haas, P. M., Keohane, R. O., \& Levy, M. A. (1993). Institutions for the Earth: Sources of Effective International Environmental Protection. Cambridge, MA: MIT Press.

Hartwick, J. M. (1990). Natural Resources, National Accounts, and Economic Depreciation. Journal of Public Economics, 43, 291-304. http://dx.doi.org/10.1016/0047-2727(90)90002-Y

HELCOM (2009). Marine Litter in the Baltic Sea Region: Assessment and Priorities for Response. Helsinki, 20 p. 
Ho, R. K., \& Joyce, J. (2004). Building Local Capacity through Coastal Strategy Development in Sihanoukville, Cambodia. Tropical Coast, Coast to Coast. From Demonstration to Replication, 11, 42-46.

International Collective in Support of Fishworkers (2004). Gender Agenda: Women in Fisheries: A Collection of Articles from SAMUDRA Report. India: ICSF.

International Collective in Support of Fishworkers (ICSF) (2001). Forging Unity: Coastal Communities and the Indian Ocean's Future. Proceedings of the Indian Ocean Conference, Chennai, 9-13 October 2001.

IOC/UNESCO, IMO, FAO, UNDP (2011). A Blueprint for Ocean and Coastal Sustainability. Paris: IOC/UNESCO. http://www.unesco.org/new/fileadmin/MULTIMEDIA/HQ/SC/pdf/interagency_blue_paper_ocean_rioPlus20.pdf

Jørgensen, M. W., \& Philipps, L. J. (2002). Discourse Analysis as Theory and Method. London, Thousand Oaks and New Delhi: SAGE Publications.

Kaul, I. (2013). Global Public Goods. A Concept for Framing the Post-2015 Agenda? Discussion Paper 2/2013, German Development Institute.

Keller, R., Hirseland, A., Schneider, W., \& Viehöver, W. (Eds.) (2010). Handbuch Sozialwissenschaftliche Diskursanalyse: Band 2: Forschungspraxis. Wiesbaden: VS Verlag für Sozialwissenschaften.

Kimball, L. A. (2005). The International Legal Regime of the High Seas and the Seabed beyond the Limits of National Jurisdiction and Options for Cooperation for the Establishment of Marine Protected Areas (MPAs) in Marine Areas beyond the Limits of National Jurisdiction. Technical Series No. 19, Montreal: Secretariat of the Convention on Biological Diversity, $64 \mathrm{p}$.

Laclau, E. (1990). New Reflections on the Revolution of Our Time. London: Routledge, Chapman \& Hall, Incorporated.

Laclau, E. (1996). Emancipation(s). London: Verso.

Laclau, E. (2000a). Identity and Hegemony: The Role of Universality in the Constitution of Political Logics. In J. P. Butler, E. Laclau, \& S. Zizek (Eds.), Contingency, Hegemony, Universality: Contemporary Dialogues on the Left (pp. 44-89). London: Verso.

Laclau, E. (2004). Glimpsing the Future. In S. Critchley, \& Marchart, O. (Eds.), A Critical Reader (pp. 279-328). London and New York: Routledge.

Laclau, E., \& Mouffe, C. (2001[1985]). Hegemony and Socialist Strategy. Towards a Radical Democratic Politics. London and New York: Verso.

Laclau, E., \& Mouffe, C. (2006). Hegemonie und radikale Demokratie. Zur Dekonstruktion des Marxismus. 3. Aufl. Wien: Passagen-Verlag.

Madina, M. (Ed.) (2008). The Beauty of the Beast. The Present and Future of Elasmobranches in Europe. Madrid, Brussels, Washington, Juneau and Providencia: OCEANA.

Maribus (Ed.) (2010). World Ocean Review 2010: Mit den Meeren leben. Hamburg: Maribus in cooperation with the Cluster of Excellence "The Future Ocean" and the International Ocean Institute (IOI), Halifax, Ca.

Methmann, C. P. (2010). “Climate Protection” as Empty Signifier: A Discourse Theoretical Perspective on Climate Mainstreaming in World Politics. http://mil.sagepub.com/content/early/2010/10/16/0305829810383606

Mora, C., Wei, C. L., Rollo, A., Amaro, T., Baco, A. R., Billett, D. et al. (2013). Biotic and Human Vulnerability to Projected Changes in Ocean Biogeochemistry over the 21st Century. PLoS Biology, 11, e1001682. http://dx.doi.org/10.1371/journal.pbio.1001682

Nabers, D. (2007). Crises, Hegemony and Change in the International System: A Conceptual Framework. GIGA Working Papers, No. 50. http://dx.doi.org/10.2139/ssrn.999332

Nabers, D. (2009). Filling the Void of Meaning: Identity Construction in US Foreign Policy after September 11, 2001. Foreign Policy Analysis, 5, 191-214. http://dx.doi.org/10.1111/j.1743-8594.2009.00089.x

National Research Council (1999). Our Common Journey: A Transition toward Sustainability. Washington DC: National Academy Press.

Neumayer, E. (1999). Weak versus Strong Sustainability. Cheltenham: Edward Elgar.

OSPAR Commission (2008). Protecting and Conserving the North-East Atlantic and Its Resources. Annual Report of the OSPAR Commission 2007/08.

Ott, K. (2014). Institutionalizing Strong Sustainability: A Rawlsian Perspective. Sustainability, 6, 894-912. http://dx.doi.org/10.3390/su6020894

Parris, T. M., \& Kates, R. W. (2003). Characterizing and Measuring Sustainable Development. Annual Review of Environment and Resources, 28, 13.1-13.28.

Pearce, D., Markandya, A., \& Barbier, E. B. (1989). Blue Print for a Green Economy. London: Earthscan.

Pitcher, T. J., \& Cheung, W. W. L. (2013). Fisheries: Hope or Despair? Marine Pollution Bulletin, 74, 506-516. http://dx.doi.org/10.1016/j.marpolbul.2013.05.045 
Rio Declaration on Environment and Development (1992). http://www.un.org/documents/ga/conf151/aconf15126-1annex1.htm.

Robinson, J. (2004). Squaring the Circle? Some Thoughts on the Idea of Sustainable Development. Ecological Economics, 48, 369-384. http://dx.doi.org/10.1016/j.ecolecon.2003.10.017

Royal Society (2005). Ocean Acidification Due to Increasing Atmospheric Carbon Dioxide. Policy Document 12/05. https://royalsociety.org/ /media/Royal_Society_Content/policy/publications/2005/9634.pdf

Sanders, J. S., Gréboval, D., \& Hjort, A. (2011). Marine Protected Areas: Country Case Studies on Policy, Governance and Institutional Issues. FAO Fisheries and Aquaculture Technical Paper, No. 556/1, Rome: FAO.

Schultz, J., Brand, F., Kopfmüller, J., \& Ott, K. (2008). Building a “Theory of Sustainable Development”: Two Salient Conceptions within the German Discourse. International Journal of Environment and Sustainable Development, 7, 465-482. http://dx.doi.org/10.1504/IJESD.2008.022390

SCOR/IOC Symposium Planning Committee (2004). Meeting Report: The Ocean in a High-CO ${ }_{2}$ World. Oceanography, 17, 72-78.

Scott, M. (2012). WordSmith 6.0. http://www.lexically.net/wordsmith/

Service, R. E. (2012). Rising Acidity Brings an Ocean of Trouble. Science, 337, 146-148. http://dx.doi.org/10.1126/science.337.6091.146

Skjærseth, J. B. (2002b). Towards the End of Dumping in the North Sea: The Case of the Oslo Commission. In E. L. Miles (Ed.), Environmental Regime Effectiveness: Confronting Theory with Evidence (pp. 65-86). Cambridge, MA: MIT Press.

Spangenberg, J. H. (2002). Environmental Space and the Prism of Sustainability: Frameworks for Indicators Measuring Sustainable Development. Ecological Indicators, 2, 295-309. http://dx.doi.org/10.1016/S1470-160X(02)00065-1

Sweeney, D., \& Bruce, G. (2007). The City as a Learnscape-Integrating Sustainability Learning in the Townsville (Qld, Australia) Urban Environment. Pacem in Maribus XXXII Conference, Waves of Change: Women, Youth and the Sea, 5-8 November 2007, Attard, Malta.

The Global 2000 Report to the President. Entering the $21^{\text {st }}$ Century. (1980). A Report Prepared by the Council on Environmental Quality and the Department of State. In G. O. Barney (Study Director), Washington: US Government Printing Office.

Tournadre, J. (2014). Anthropogenic Pressure on the Open Ocean: The Growth of Ship Traffic Revealed by Altimeter Data Analysis. Geophysical Research Letters, 41, 7924-7932. http://dx.doi.org/10.1002/2014GL061786

Turley, C. (2005). The Other $\mathrm{CO}_{2}$ Problem. http://www.opendemocracy.net/globalization-climate change debate/article 2480.jsp

Underdal, A. (2010). Complexity and Challenges of Long-Term Environmental Governance. Global Environmental Change, 20, 386-393. http://dx.doi.org/10.1016/j.gloenvcha.2010.02.005

United Nations (2002). Report of the World Summit on Sustainable Development. Johannesburg, South Africa, 26 August-4 September 2002, New York, A/CONF.199/20.

United Nations Environment Programme. (2006). Ecosystems and Biodiversity in Deep Waters and High Seas. UNEP Regional Seas Reports and Studies No. 178, Switzerland: UNEP/IUCN.

United Nations Environmental Programme-World Conservation Monitoring Centre (UNEP-WCMC) (2008). National and Regional Networks of Marine Protected Areas: A Review of Progress. Cambridge: UNEP-WCMC.

United Nations General Assembly (1982). World Charter for Nature. A/RES/37/7. http://www.un.org/documents/ga/res/37/a37r007.htm

United Nations General Assembly (2005). Oceans and the Law of the Sea. Report of the Secretary-General. 16th Session. A/60/63. New York.

United Nations General Assembly (2006). Oceans and the Law of the Sea. Report of the Secretary-General. 61st Session, A/61/63. New York.

United Nations General Assembly (2009). Official Records. 58th Plenary Meeting. Friday, 4 December 2009. 64th Session, A/64/PV.58. New York.

United Nations General Assembly (2010). Oceans and the Law of the Sea. Report of the Secretary-General, 65th Session, A/65/69, Add. 2. New York.

United Nations General Assembly (2012). 50th Plenary Meeting. Monday, 10 December 2012. 67th Session. A/67/PV.50. New York.

United Nations General Assembly (2012). The Future We Want. Resolution Adopted by the General Assembly on 27 July 2012, 66th Session, A/RES/66/288. New York. 
Visbeck, M., Kronfeld-Goharani, U., Neumann, B., Rickels, W., Schmidt, J., van Doorn, E., Matz-Lück, N., Ott, K., \& Quaas, M. F. (2014). Securing Blue Wealth: The Need for a Special Sustainable Development Goal for the Ocean and Coasts. Marine Policy, 48, 184-191. http://dx.doi.org/10.1016/j.marpol.2014.03.005

Wang, H. (2004). Ecosystem Management and Its Application to Large Marine Ecosystems: Science, Law, and Politics. Ocean Development \& International Law, 35, 41-74. http://dx.doi.org/10.1080/00908320490264382

WBGU, Wissenschaftlicher Beirat der Bundesregierung Globale Umweltveränderungen (2013). Welt im Wandel. Menschheitserbe Meer. Hauptgutachten. Berlin: WBGU.

WBGU, Wissenschaftlicher Beirat der Bundesregierung Globale Umweltveränderungen (1998). Welt im Wandel, Strategien zur Bewältigung globaler Umweltrisiken. Berlin: WBGU.

Williams, C. C., \& Millington, A. C. (2004). The Diverse and Contested Meanings of Sustainable Development. The Geographical Journal, 170, 99-104. http://dx.doi.org/10.1111/j.0016-7398.2004.00111.x

World Bank Institute (2004). Capacity Enhancement for Social Development: Building on Local Context and Process. http://web.worldbank.org/archive/website01001/WEB/IMAGES/CAPACITY.PDF

World Commission on Environment and Development (1987). Our Common Future. Oxford, New York: Oxford University Press.

World Meteorological Organization (2010). Implementation Plan for the Global Observing System for Climate in Support of the UNFCCC. http://www.wmo.int/pages/prog/gcos/Publications/gcos-138.pdf

World Summit on Sustainable Development (2002). Plan of Implementation. http://www.un.org/esa/sustdev/documents/WSSD_POI_PD/English/WSSD_PlanImpl.pdf

Worm, B., \& Branch, T. A. (2012). The Future of Fish. Trends in Ecology \& Evolution, 27, 594-599. http://www.fmap.ca/ramweb/papers-total/Worm Branch 2012.pdf http://dx.doi.org/10.1016/j.tree.2012.07.005

Young, O. R., Osherenko, G., Ekstrom, J., Crowder, L. B., Ogden, J., Wilson, J. A., Day, J. C., Douvere, F., Ehler, C. N., McLeod, K. L., Halpern, B. S., \& Peach, R. (2007). Solving the Crisis in Ocean Governance: Place-Based Management of Marine Ecosystems. Environment: Science and Policy for Sustainable Development, 49, 20-32. http://dx.doi.org/10.3200/ENVT.49.4.20-33 


\section{Appendix 1: Abbreviations}

\begin{tabular}{|c|c|}
\hline AMAP & Arctic Monitoring Assessment Programme \\
\hline AoA & Assessment of Assessment \\
\hline CBD & Convention on Biological Diversity \\
\hline CCAMLR & Commission for the Conservation of Antarctic Marine Living Resources \\
\hline CLCS & Commission on the Limits of the Continental Shelf \\
\hline COFI & Committee on Fisheries \\
\hline COL & Consortium of Ocean Leadership \\
\hline $\mathrm{COP}$ & Conference of Parties \\
\hline COS & Center for Oceans Solutions \\
\hline CSI & Cetacean Society International \\
\hline DOALOS & Division for Ocean Affairs and the Law of the Sea \\
\hline DSCC & Deep Sea Conservation Coalition \\
\hline EEZs & Exclusive Economic Zones \\
\hline EMSEA & European Marine Science Educators Association \\
\hline EU & European Union \\
\hline FAO & Food and Agriculture Organisation \\
\hline GCRMN & Global Coral Reef Monitoring Network \\
\hline GDP & Gross Domestic Product \\
\hline GEF & Global Environmental Facility \\
\hline GESAMP & Joint Group of Experts on the Scientific Aspects of Marine Environmental Protection \\
\hline GHG & Greenhouse Gases \\
\hline GOBI & Global Ocean Biodiversity Initiative \\
\hline GOF & Global Ocean Forum \\
\hline GOOS & Global Ocean Observing System \\
\hline GSDR & Global Sustainable Development Report \\
\hline HELCOM & Helsinki Commission \\
\hline HLPF & High-Level Political Forum on Sustainable Development \\
\hline HLPGS & High-Level Panel on Global Sustainability \\
\hline ICES & International Council for the Exploration of the Sea \\
\hline ICM & Integrated coastal management \\
\hline ICP & Informal Consultative Process (on Oceans and the Law of the Sea) \\
\hline ICRI & International Coral Reef Initiative \\
\hline ICSF & International Collective in Support of Fishworkers \\
\hline ICSU & International Council for Science \\
\hline ICSU/SCOR & SCOR Scientific Committee on Ocean Research \\
\hline ICSU/SCAR & SCAR Scientific Committee on Antarctic Research \\
\hline ICZM & Integrated Coastal Zone Management \\
\hline IGO & Intergovernmental Organisation \\
\hline IMBER & Integrated Marine Biogeochemistry and Ecosystem Research \\
\hline IMO & International Maritime Organisation \\
\hline IOC & Intergovernmental Oceanographic Commission \\
\hline IOCCARIBE & IOC Sub-Commission for the Caribbean and Adjacent Regions \\
\hline IOCWESTPAC & IOC Sub-Commission for the Western Pacific \\
\hline IOCAFRICA & IOC Subcommittee for Africa and the Adjacent Island States \\
\hline IODE & International Oceanographic Data and Information Exchange \\
\hline IOI & International Ocean Institute \\
\hline IPCC & Intergovernmental Panel on Climate Change \\
\hline IPSO & International Programme on the State of the Ocean \\
\hline ISA & International Seabed Authority \\
\hline IUCN & International Union for Conservation of Nature \\
\hline IUU & Illegal, Unreported and Unregulated \\
\hline
\end{tabular}




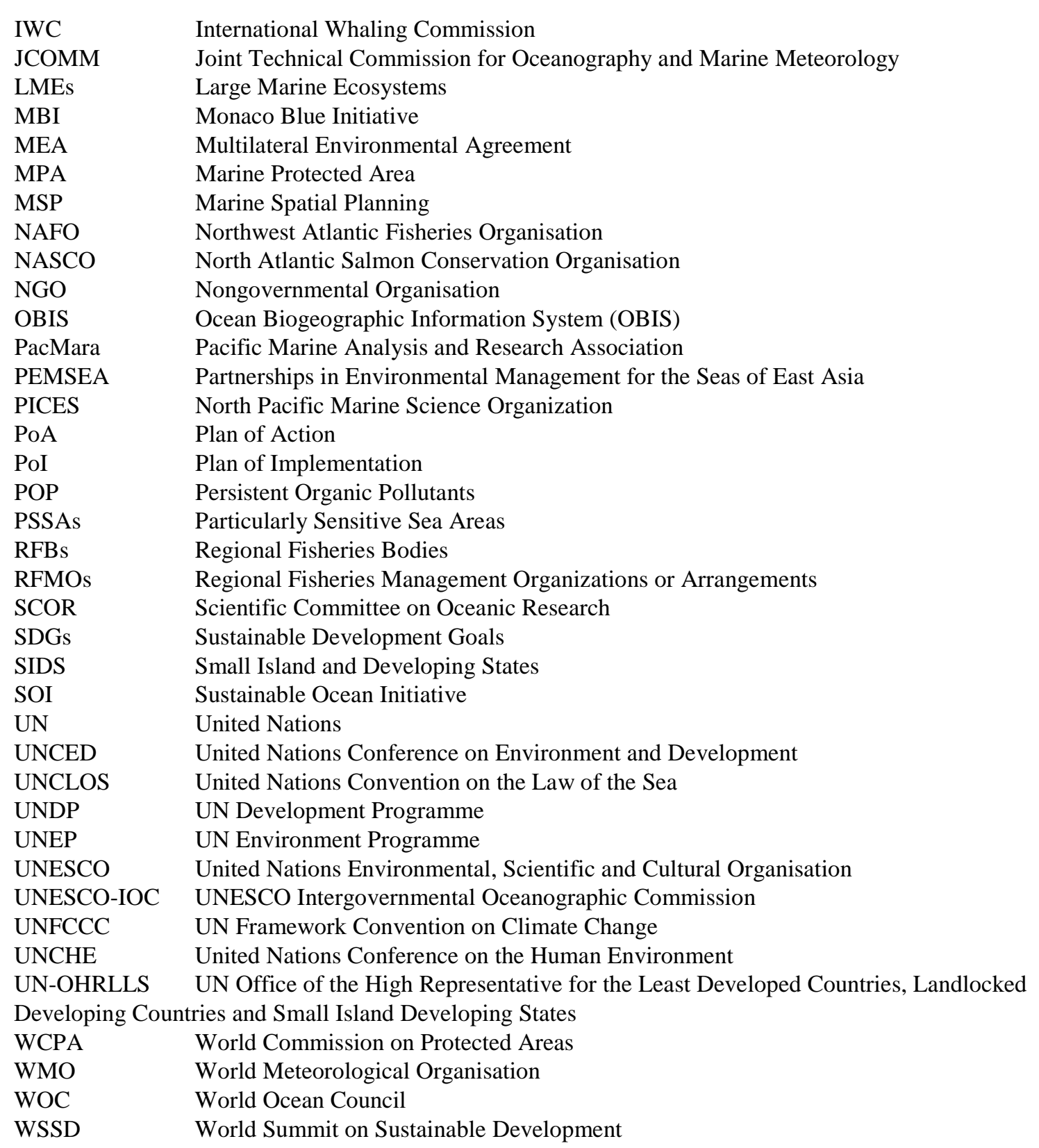

